\title{
Four new species of Acanthobothrium van Beneden, 1849 (Cestoda: Onchoproteocephalidea) from the spotted skate, Raja straeleni Poll, off the Western Cape, South Africa
}

\author{
Linda Van Der Spuy ${ }^{1}$, Nico J. Smit ${ }^{1}$ and Bjoern C. Schaeffner ${ }^{1,2}$ \\ ${ }^{1}$ Water Research Group, Unit for Environmental Sciences and Management, Potchefstroom Campus, North-West University, \\ Potchefstroom, South Africa; \\ ${ }^{2}$ South African Shark Conservancy, Old Harbour, Hermanus, South Africa
}

\begin{abstract}
The examination of eight spotted skates, Raja straeleni Poll, resulted in the discovery of four new species of Acanthobothrium van Beneden, 1849, namely A. microhabentes sp. n., A. microtenuis sp. n., A. crassus sp. n., and A. dolichocollum sp. n., located off the Western Cape of South Africa. With a total of over 200 valid species of Acanthobothrium recognised worldwide, the use of an integrative approach becomes imperative in the interest of simplifying interspecific comparisons between congeners. In accordance with this, the four new species were incorporated into the category classification system established by Ghoshroy and Caira in 2001, where they were identified as category 2 species, which, at present, includes 47 recognised species of Acanthobothrium. Nevertheless, each of the four new species exhibits postovarian testes, a most intriguing and highly unusual feature among Acanthobothrium, instantly differentiating them from most congeners. This feature has been reported in 12 congeners, which have previously been considered to be restricted to waters of the Indo-Pacific Ocean. Not only do the four new congeners represent the first species of Acanthobothrium reported from southern Africa, but they also represent the first reported species with postovarian testes from the southern Atlantic Ocean. Regarding the legitimacy of the four new species, only two other category 2 species are reported to exhibit this feature, namely $A$. popi Fyler, Caira et Jensen, 2009, and A. bobconniorum Fyler et Caira, 2010, to which the four congeners were compared to. Acanthobothrium microhabentes sp. $\mathrm{n}$. is the smallest of the congeners and differs from A. popi and A. bobconniorum by having fewer testes and postovarian testes, a shorter body, fewer proglottids, a shorter scolex, and longer cephalic peduncle. Acanthobothrium microtenuis sp. $\mathrm{n}$. differs from A. popi and A. bobconniorum by having fewer testes and postovarian testes, a shorter scolex, longer cephalic peduncle, and the possession of columnar spinitriches on the anterior region of the terminal proglottid. Acanthobothrium crassus sp.n. differs from A. popi and A. bobconniorum by having fewer postovarian testes, a narrower cirrus-sac, larger vitelline follicles, and a longer cephalic peduncle. Acanthobothrium dolichocollum sp. $\mathrm{n}$. is the longest of the four new species and differs from A. popi and A. bobconniorum by having fewer postovarian testes, more postporal testes, a larger body, more proglottids, larger testes and vitelline follicles, and an exceptionally long cephalic peduncle. Apart from differences in overall size, the four new species differ in a combination of measurements for the scolex, vitelline follicles, muscular pad and cephalic peduncle, and the number of proglottids and testes. The four species were recovered from a previously unexplored host and locality, expanding the host associations and geographical distribution of the genus.
\end{abstract}

Keywords: Marine fish parasites, elasmobranchs, tapeworms, taxonomy, biodiversity, new species

Over the past few decades, researchers have gained remarkable new perspectives on our understanding of the vast number of cestodes infecting elasmobranchs across the world's oceans (Caira and Jensen 2014, 2017). Of the nine cestode orders known to parasitise elasmobranchs, members of the Onchoproteocephalidea Caira, Jensen, Waeschenback, Olsen et Littlewood, 2014 are the only tapeworms known to parasitise other vertebrate groups such as bony fishes, reptiles and amphibians (Onchoproteocephalidea I) ) (de Chambrier et al. 2017) as well as elasmobranchs (Onchoproteocephalidea II) (Caira and Jensen 2014, 2017).
To date, the Onchoproteocephalidea II consists of 12 valid genera, with an estimated diversity of more than 1,154 species (Caira and Jensen 2017, Caira et al. 2018). Members of this order are known to exhibit an oioxenous host specificity, with each species infecting a single definitive host species (Caira et al. 2018). They are, however, hosted by a wide range of elasmobranch groups, with the majority of species described to parasitise stingrays (Campbell and Beveridge 2002, Ivanov 2005, Fyler 2011, Maleki et al. 2015). Members of the Onchoproteocephalidea II are known from all but four of the 25 batoid families (Caira et 


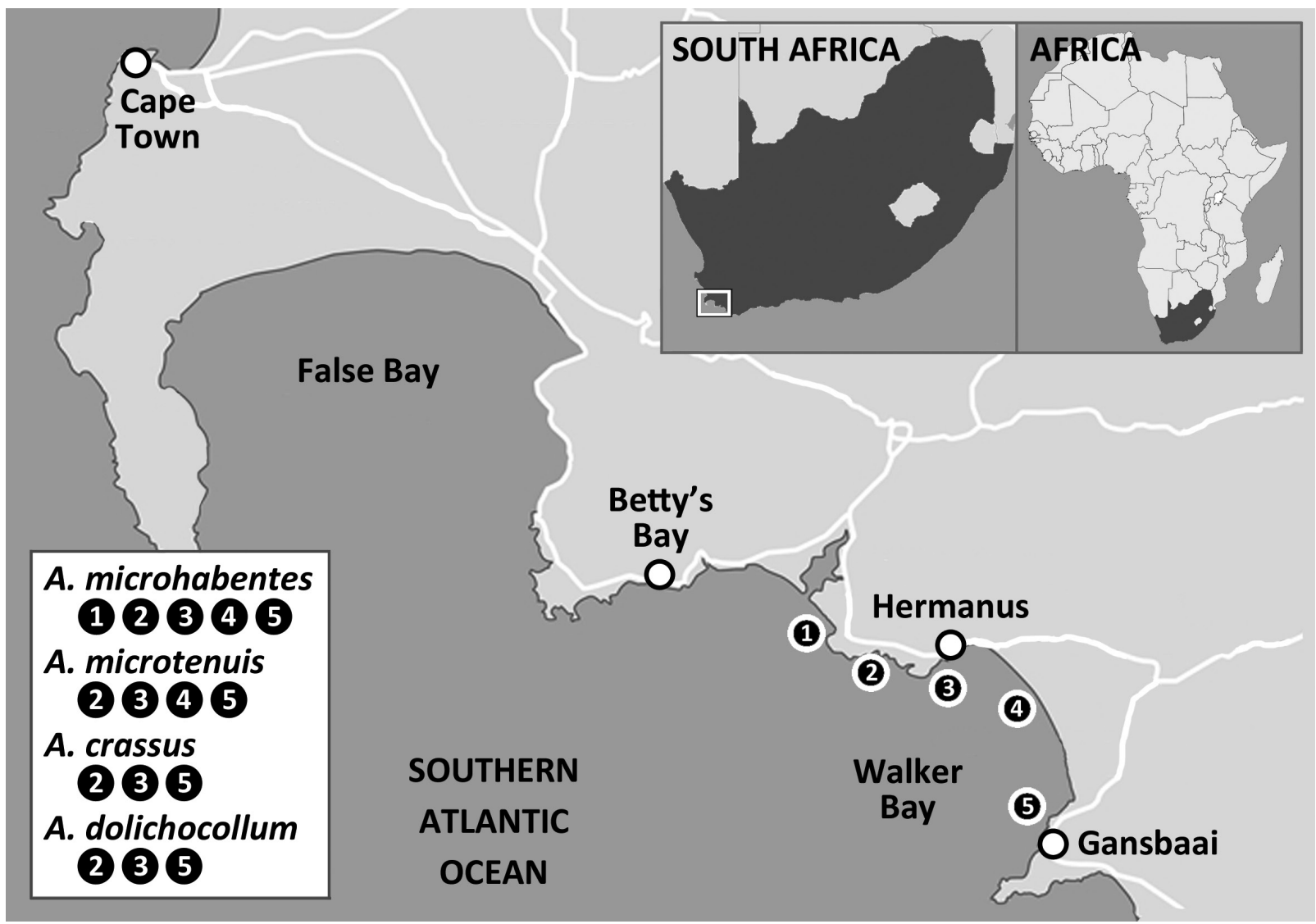

Fig. 1. Map indicating the sampling localities of species of Acanthobothrium van Beneden, 1849.

al. 2017), and have been reported in four of the seven orders of sharks. Species parasitising sharks typically occur in carcharhiniform, heterodontiform and squaliform sharks (Caira et al. 2017).

Although having a cosmopolitan distribution, the majority of records of onchoproteocephalideans from elasmobranchs were derived from species of Acanthobothrium van Beneden, 1849 in tropical and subtropical waters (Caira and Jensen 2014). Acanthobothrium is the species-richest genus of all elasmobranch-infecting cestode genera (Maleki et al. 2015, Caira et al. 2018). The genus is characterised by a scolex with four bothridia, each containing one pair of bi-pronged hooks.

Despite the large number of valid species of the genus, it is estimated that an additional 800, if not more, species of Acanthobothrium are yet to be discovered worldwide (Caira et al. 2017). One region that potentially hosts many undescribed species of Acanthobothrium is the extremely biodiverse, biogeographical realm of Temperate southern Africa (sensu Spalding et al. 2007). The diversity, biogeography and biology of elasmobranchs off southern Africa have been well documented, with 204 elasmobranch species reported from this region (Ebert and van Hees 2015). However, only 18 of these species have been examined for cestode infections (Schaeffner and Smit 2019).

As part of a larger study on the biodiversity of marine fish parasites of southern Africa, specimens of Acanthobothrium were collected from Raja straeleni Poll (Rajidae) off the Western Cape of South Africa. This study provides information on the taxonomic status of species belonging to the genus Acanthobothrium, based on light and scanning electron microscopy, leading to the description of four species new to science.

\section{MATERIALS AND METHODS}

Eight specimens of Raja straeleni, seven males and one female, were collected by longline. One specimen was collected during October 2018 from Vermont (-34.4927, 19.4136), whereas the other seven specimens were collected in February 2019 from Walker Bay, Hermanus (-34.5283, 19.4102), Hawston (-34.4419, 19.3697), and De Kelders $(-34.5925,19.2925)$. Figure 1 indicates the sampling localities from which each species was obtained. Ethical approval for this project was received from the North-West University Animal Care, Health and Safety, Research Ethics Committee (NWU-AnimCareREC) with ethics number NWU-00065-19-A5. Permits for the collection and possession of batoid specimens for the purpose of research were issued by the South African Department of Agriculture, Forestry and Fisheries (permit nos. RES2019/45 and RES2019/105 issued to BCS; RES2019/58 and RES2019/61 issued to the South African Shark Conservancy).

Skates were sacrificed by means of an adjunctive procedure of trauma to the neurocranium, followed immediately by pithing of the brain. The body cavity was opened with a mid-ventral incision to remove the spiral intestine. Spiral intestines and their contents were fixed in hot, $4 \%$ formalin for morphological observations, and ultimately transferred to $70 \%$ ethanol. Specimens of Acanthobothrium were hand-picked from the spiral intestines 
Table 1. Metrical information of the new species of Acanthobothrium van Beneden, 1849. Information are presented as the mean, followed by the standard deviation and the number of worms examined. All measurements are in micrometres, unless stated otherwise. Abbreviations: L - length ; $\mathrm{N}$ - number; $\mathrm{W}$ - width.

\begin{tabular}{|c|c|c|c|c|}
\hline Character & $\begin{array}{c}\text { Acanthobothrium } \\
\text { microhabentes } \mathrm{sp} . \mathrm{n} .\end{array}$ & $\begin{array}{l}\text { Acanthobothrium } \\
\text { microtenuis sp. } \mathrm{n} .\end{array}$ & $\begin{array}{l}\text { Acanthobothrium } \\
\text { crassus sp. n. }\end{array}$ & $\begin{array}{c}\text { Acanthobothrium } \\
\text { dolichocollum sp. } \mathrm{n} \text {. }\end{array}$ \\
\hline Total length (mm) & $2.13 \pm 0.51 ; 25$ & $3.22 \pm 0.73 ; 14$ & $6.62 \pm 0.90 ; 5$ & $9.15 \pm 1.00 ; 6$ \\
\hline Scolex L & $303 \pm 2 ; 25$ & $314 \pm 3 ; 14$ & $446 \pm 3 ; 5$ & $413 \pm 3 ; 6$ \\
\hline Scolex W & $232 \pm 8 ; 22$ & $261 \pm 13 ; 14$ & $324 \pm 11 ; 4$ & $353 \pm 6 ; 6$ \\
\hline Bothridium W & $109 \pm 3 ; 20$ & $120 \pm 6 ; 14$ & $160 \pm 14 ; 5$ & $131 \pm 3 ; 6$ \\
\hline Anterior (A) loculus L & $101 \pm 3 ; 22$ & $141 \pm 8 ; 14$ & $180 \pm 4 ; 5$ & $187 \pm 10 ; 6$ \\
\hline Middle (M) loculus L & $47 \pm 1 ; 22$ & $52 \pm 4 ; 14$ & $82 \pm 6 ; 5$ & $80 \pm 5 ; 6$ \\
\hline Posterior $(\mathrm{P})$ loculus L & $51 \pm 2 ; 22$ & $63 \pm 4 ; 14$ & $81 \pm 4 ; 5$ & $67 \pm 4 ; 6$ \\
\hline Loculus L ratio (A: M: P) & $1.0: 2.2 \pm 0.1: 2.0 \pm 0.1 ; 22$ & $1.0: 2.7 \pm 0.3: 2.2 \pm 0.2 ; 14$ & $1.0: 2.2 \pm 0.2: 2.2 \pm 0.2 ; 5$ & $1.0: 2.3 \pm 0.1: 2,80 \pm 0.2 ; 6$ \\
\hline Muscular pad L & $70 \pm 3 ; 23$ & $70 \pm 9 ; 13$ & $95 \pm 5 ; 5$ & $80 \pm 3 ; 6$ \\
\hline Muscular pad W & $104 \pm 4 ; 21$ & $110 \pm 3 ; 13$ & $105 \pm 2 ; 5$ & $123 \pm 2 ; 6$ \\
\hline Accessory sucker L & $40 \pm 2 ; 22$ & $48 \pm 2 ; 12$ & $46 \pm 2 ; 5$ & $54 \pm 2 ; 6$ \\
\hline Accessory sucker W & $36 \pm 3 ; 22$ & $41 \pm 3 ; 12$ & $43 \pm 3 ; 5$ & $49 \pm 1 ; 6$ \\
\hline Lateral hook A & $42 \pm 2 ; 21$ & $46 \pm 4 ; 14$ & $44 \pm 3 ; 5$ & $41 \pm 6 ; 4$ \\
\hline Lateral hook B & $81 \pm 5 ; 21$ & $85 \pm 9 ; 14$ & $77 \pm 5 ; 5$ & $72 \pm 4 ; 4$ \\
\hline Lateral hook C & $72 \pm 6 ; 21$ & $77 \pm 11 ; 14$ & $68 \pm 6 ; 5$ & $61 \pm 8 ; 4$ \\
\hline Lateral hook D & $117 \pm 7 ; 21$ & $122 \pm 9 ; 14$ & $114 \pm 5 ; 5$ & $105 \pm 7 ; 4$ \\
\hline Medial hook A' & $41 \pm 3 ; 25$ & $47 \pm 4 ; 14$ & $43 \pm 2 ; 5$ & $45 \pm 2 ; 4$ \\
\hline Medial hook B' & $81 \pm 5 ; 25$ & $84 \pm 6 ; 14$ & $78 \pm 7 ; 5$ & $70 \pm 6 ; 4$ \\
\hline Medial hook C' & $75 \pm 6 ; 25$ & $80 \pm 6 ; 14$ & $72 \pm 5 ; 5$ & $67 \pm 6 ; 4$ \\
\hline Medial hook D' & $116 \pm 6 ; 25$ & $125 \pm 6 ; 14$ & $115 \pm 8 ; 5$ & $110 \pm 8 ; 4$ \\
\hline Cephalic peduncle L & $521 \pm 123 ; 22$ & $1,044 \pm 320 ; 14$ & $1,685 \pm 254 ; 5$ & $2,998 \pm 970 ; 6$ \\
\hline Cephalic peduncle W & $52 \pm 3 ; 25$ & $63 \pm 3 ; 14$ & $91 \pm 2 ; 5$ & $69 \pm 2 ; 6$ \\
\hline Proglottid N & $8 \pm 1 ; 20$ & $13 \pm 2 ; 9$ & $29 \pm 2 ; 5$ & $37 \pm 6 ; 6$ \\
\hline Immature proglottid $\mathrm{N}$ & $7 \pm 1 ; 20$ & $12 \pm 2 ; 9$ & $27 \pm 2 ; 5$ & $35 \pm 6 ; 6$ \\
\hline Mature proglottid N & $1 \pm 1 ; 20$ & $1 \pm 1 ; 9$ & $2 \pm 1 ; 5$ & $2 \pm 1 ; 6$ \\
\hline Genital pore position (\%) & $69 \pm 5 ; 22$ & $61 \pm 2 ; 11$ & $59 \pm 4 ; 5$ & $60 \pm 4 ; 6$ \\
\hline Terminal proglottid L & $770 \pm 155 ; 22$ & $886 \pm 128 ; 12$ & $1,107 \pm 128 ; 5$ & $1,227 \pm 149 ; 6$ \\
\hline Terminal proglottid W & $156 \pm 23 ; 22$ & $163 \pm 30 ; 12$ & $222 \pm 20 ; 5$ & $234 \pm 27 ; 6$ \\
\hline Terminal proglottid ratio (L: W) & $5 \pm 1 ; 22$ & $6 \pm 1 ; 12$ & $6 \pm 2 ; 5$ & $6 \pm 3 ; 6$ \\
\hline Cirrus-sac L & $68 \pm 6 ; 24$ & $119 \pm 5 ; 14$ & $128 \pm 5 ; 5$ & $124 \pm 2 ; 6$ \\
\hline Cirrus-sac W & $40 \pm 4 ; 24$ & $58 \pm 6 ; 14$ & $52 \pm 3 ; 5$ & $70 \pm 1 ; 6$ \\
\hline Testis N & $27 \pm 3 ; 23$ & $29 \pm 3 ; 12$ & $43 \pm 2 ; 5$ & $36 \pm 3 ; 6$ \\
\hline Postporal testis N & $5 \pm 1 ; 20$ & $8 \pm 1 ; 12$ & $9 \pm 1 ; 5$ & $11 \pm 1 ; 6$ \\
\hline Postovarian testis $\mathrm{N}$ & $1 \pm 1 ; 20$ & $2 \pm 1 ; 12$ & $2 \pm 1 ; 5$ & $3 \pm 1 ; 6$ \\
\hline Testis L & $42 \pm 5 ; 23$ & $54 \pm 7 ; 14$ & $49 \pm 4 ; 5$ & $57 \pm 3 ; 6$ \\
\hline Testis W & $29 \pm 4 ; 23$ & $35 \pm 4 ; 14$ & $41 \pm 3 ; 5$ & $44 \pm 3 ; 6$ \\
\hline Poral ovarian arm L & $354 \pm 82 ; 19$ & $413 \pm 65 ; 11$ & $542 \pm 95 ; 5$ & $589 \pm 54 ; 6$ \\
\hline Aporal ovarian arm L & $386 \pm 110 ; 19$ & $477 \pm 94 ; 11$ & $585 \pm 107 ; 5$ & $600 \pm 46 ; 6$ \\
\hline Ovary W & $68 \pm 8 ; 20$ & $106 \pm 7 ; 12$ & $109 \pm 7 ; 5$ & $116 \pm 4 ; 6$ \\
\hline Vitelline follicle L & $9 \pm 2 ; 24$ & $16 \pm 3 ; 14$ & $17 \pm 3 ; 5$ & $20 \pm 2 ; 6$ \\
\hline Vitelline follicle $\mathrm{W}$ & $16 \pm 3 ; 24$ & $27 \pm 5 ; 14$ & $35 \pm 2 ; 5$ & $38 \pm 3 ; 6$ \\
\hline
\end{tabular}

and contents. They were hydrated in a graded ethanol series and stained in Delafield's haematoxylin, dehydrated in a graded ethanol series, cleared in clove oil, and permanently mounted on microscope slides using Canada balsam. Images of various internal organs and characteristic body structures used for measurements were acquired using a Nikon Y-TV55 video camera mounted on a Nikon ECLIPSE Ni microscope (Nikon, Tokyo, Japan). Image analysis software Image Pro Express (Nikon, Japan) was used to obtain all necessary measurements for descriptive analyses.

All measurements were taken according to specifications given by Ghoshroy and Caira (2001). Measurements are given both in text descriptions as well as in tabular form. Text descriptions include the range of measurements taken, whereas Table 1 presents metrical data as the mean, followed by standard deviation and number of specimens examined. Measurements are all presented in micrometres, with the exception of the total length, which is presented in millimetres. Drawings were made by the use of a drawing attachment tube.
Two to three specimens of each species were used for scanning electron microscopy (SEM). Each specimen selected for SEM observation was cleaned by lightly brushing the surface of the scolex. Cleaned specimens were then dehydrated in a graded ethanol series and either placed in hexamethyldisilisane (HMDS) overnight, or dried by critical point drying. Specimens were mounted onto carbon tape, placed on aluminium stubs and sputter-coated with either 20 to $30 \mathrm{~nm}$ of gold/palladium (SPI-module, SPI Supplies, Pennsylvania, USA), or first with carbon (Emscope TB500, Quorum Technologies, Puslinch, Ontario, USA), followed by 20 to $30 \mathrm{~nm}$ gold/palladium (Eiko IB2 ion coater, Eiko, Japan).

Specimens were examined with a Phenom Pro Desktop scanning electron microscope (ThermoScientific, Waltham, Massachusetts, USA) and a FEI Nova NanoSEM 450 scanning electron microscope (FEI, Hillsboro, Oregon, USA). Images were taken of similar regions of the strobila and scolex, aiding in microthrix comparisons among species. Images of microtriches of immature proglottids were taken directly posterior to the cephalic peduncle. 
Table 2. Information (sex, size, weight) on host specimens of Raja straeleni Poll (Rajiformes: Rajidae), including sampling sites and presence or absence of species of Acanthobothrium van Beneden, 1849.

\begin{tabular}{|c|c|c|c|c|c|c|c|c|c|}
\hline $\begin{array}{l}\text { Collection } \\
\text { code }\end{array}$ & Sex & $\begin{array}{l}\text { Length } \\
(\mathrm{cm})\end{array}$ & $\begin{array}{l}\text { Disc width } \\
(\mathrm{cm})\end{array}$ & $\begin{array}{l}\text { Weight } \\
\text { (g) }\end{array}$ & Locality & $\begin{array}{l}\text { Acanthobothrium } \\
\text { microhabentes } \\
\text { sp. n. }\end{array}$ & $\begin{array}{l}\text { Acanthobothrium } \\
\text { microtenuis sp. } \mathrm{n} \text {. }\end{array}$ & $\begin{array}{l}\text { Acanthobothrium } \\
\text { crassus } \text { sp. } \mathrm{n} .\end{array}$ & $\begin{array}{l}\text { Acanthobothrium } \\
\text { dolichocollum } \\
\text { sp. n. }\end{array}$ \\
\hline HE18-15 & $\mathrm{M}$ & 64.9 & 46.5 & 1,900 & Vermont, SA & + & + & + & + \\
\hline HE19-01 & M & 69.5 & 46.0 & 2,290 & Hermanus, SA & + & + & - & + \\
\hline HE19-02 & M & 68.0 & 48.0 & 2,550 & Hermanus, SA & - & + & - & + \\
\hline HE19-05 & M & 67.5 & 47.5 & 4,250 & Hermanus, SA & + & + & + & - \\
\hline HE19-09 & $\mathrm{F}$ & 73.1 & 53.4 & 6,630 & Hermanus, SA & - & + & - & - \\
\hline HE19-10 & M & 67.0 & 46.8 & 1,880 & Hermanus, SA & + & + & - & - \\
\hline HE19-11 & M & 74.2 & 48.6 & 2,250 & Hawston, SA & + & - & - & - \\
\hline HE19-12 & M & 68.2 & 45.8 & 1,820 & De Kelders, SA & + & + & + & + \\
\hline
\end{tabular}

Abbreviations: + - present ; - - absent.

The presence of additional microthrix morphologies on the terminal proglottid was noted in which case images are also provided. The specific regions of micrographs taken are indicated on SEM plates for each of the respective species.

Species allocation followed the category classification system developed by Ghoshroy and Caira (2001) to facilitate the differentiation among congeners. Following this classification system, species were characterised and assessed based on four morphological features: total length $(<$ or $>15 \mathrm{~mm})$, number of proglottids ( $<$ or $>50$ proglottids), number of testes $(<$ or $>80$ ), and symmetry or asymmetry of aporal and poral ovarian lobes. Allocating each species to a specific category consequently simplifies differentiating between congeners. Accordingly, the four new species were incorporated into this system and compared particularly to the described species assigned to the same category as each of the four new species. Since members of different categories differ from one another in either one or more of the four morphological features constituent of this classification system (Fyler and Caira 2006), this subsequently warrants the elimination of congeners designated to different categories.

Specimens have been deposited in the helminthological collection of the National Museum, Bloemfontein, South Africa (NMB), the Institute of Parasitology, Biology Centre of the Czech Academy of Sciences, České Budějovice, Czech Republic (IPCAS), and the Natural History Museum, Geneva, Switzerland (MHNG-PLAT). Specimens used for SEM were retained in the parasite collection of the Water Research Group, North-West University, South Africa.

\section{RESULTS}

Four morphologically distinct species of Acanthobothrium were collected from subsets of eight specimens of Raja straeleni measuring $64.9-74.2 \mathrm{~cm}$ in length, disc widths of 45.8-53.4 cm, and a weight of 1,820-6,630 $\mathrm{g}$ (Table 2 ). Of the eight skates, two were parasitised by all four morphotypes, two host specimens by three morphotypes, two by two morphotypes and two skates with a single morphotype. All four morphotypes were present in skates from Vermont, Walker Bay and De Kelders, but only a single morphotype was found in the skate collected at Hawston. The only female caught during the present study was parasitised by only one of the four morphotypes (Table 2).

\section{Acanthobothrium microhabentes sp. $\mathbf{n}$.}

Figs. 2, 3

ZooBank number for species:

urn: 1sid: zoobank.org: act: 26E2521F-A19F-4DBB-B86D-7D65CED10E82
Description (based on 25 whole mounts, 21 mature and four immature worms; three mature worms used for SEM observations): Worms 1.5-3.0 mm long; greatest width at level of scolex; 5-9 proglottids per worm; euapolytic. Scolex consisting of scolex proper and short cephalic peduncle. Scolex proper with four bothridia, 301-306 long by 215-248 wide. Bothridia free posteriorly, 105-115 wide; each with three loculi and specialised anterior region in form of muscular pad. Muscular pad 63-74 long by 97113 wide, falciform in shape, with pronounced posterior margin, bearing accessory sucker and one pair of hooks at posterior margin; accessory sucker $32-41$ long by $37-45$ wide. Anterior loculus (A) 99-105 long; middle loculus (M) 42-48 long; posterior loculus (P) 48-56 long; loculus length ratio (A : $\mathrm{M}: \mathrm{P}) 1: 2.2: 2$; maximum width of scolex at level of middle loculus. Velum absent.

Hooks bi-pronged, hollow, with tubercle on proximal surface of axial prong; internal channels of axial and abaxial prongs continuous, smooth; axial prongs slightly longer than abaxial prongs; lateral and medial hooks approximately equal in size. Lateral hook measurements: A 38-46, B 69-90, C 61-82, D 102-128. Medial hook measurements: A' 34-45, B' 71-87, C' 62-84, D' 105-126. Bases of lateral and medial hooks approximately equal in length; base of lateral hooks slightly overlapping base of medial hooks along medial axis of bothridium (Fig. 2D); medial hook base slightly wider than lateral hook base. Thin layer of tissue covering essentially entire length of each prong of hooks. Long cephalic peduncle 352-695 long by 47-57 wide.

Apical pad and distal bothridial surface covered with papilliform filitriches and sparsely interspersed gladiate spinitriches (Fig. 3C). Proximal bothridial surface and bothridial rims covered with gladiate spinitriches, interspersed with acicular filitriches (Fig. 3D). Cephalic peduncle densely covered with gladiate spinitriches (Fig. 3E). Strobila covered in papilliform filitriches (Fig. 3F).

Proglottids acraspedote. Immature proglottids 4-9 in number; one mature proglottid; gravid proglottids absent; terminal proglottid 484-1,093 long by 122-205 wide; terminal proglottid length to width ratio $3.5-7: 1$. Proglottids protandrous; genital pores marginal, irregularly alternating, $50-66 \%$ of proglottid length from posterior end.

Testes conspicuous in mature proglottids, irregularly oval in dorsoventral view, 32-55 long by 23-35 wide, arranged in two regular columns, one layer deep, 21-31 
A

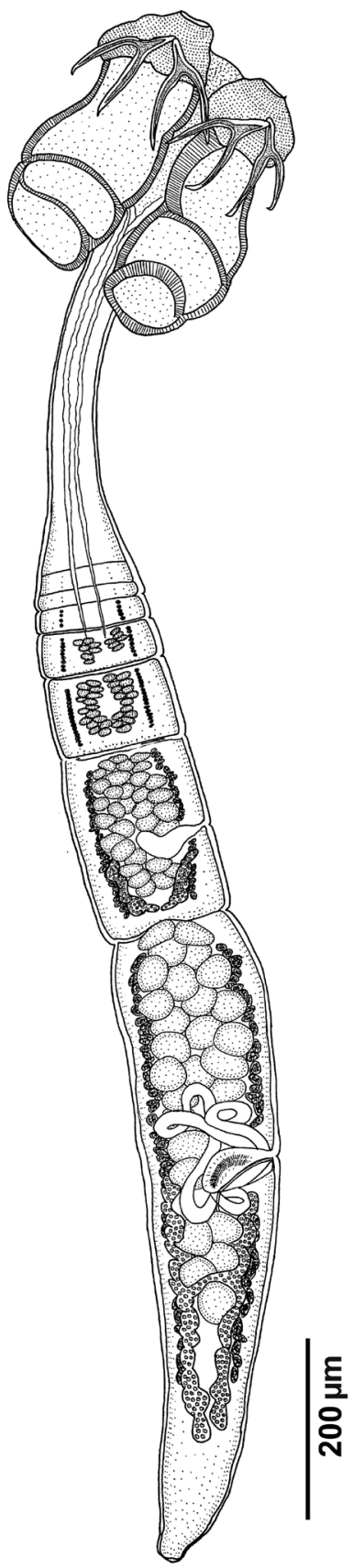

B
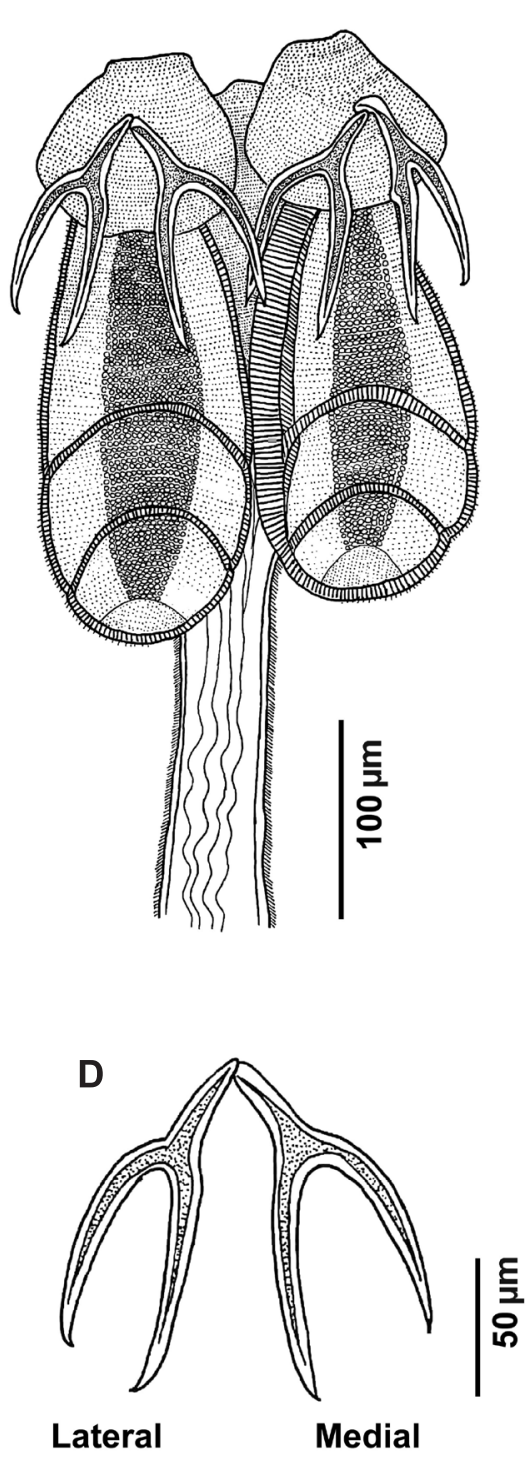

C

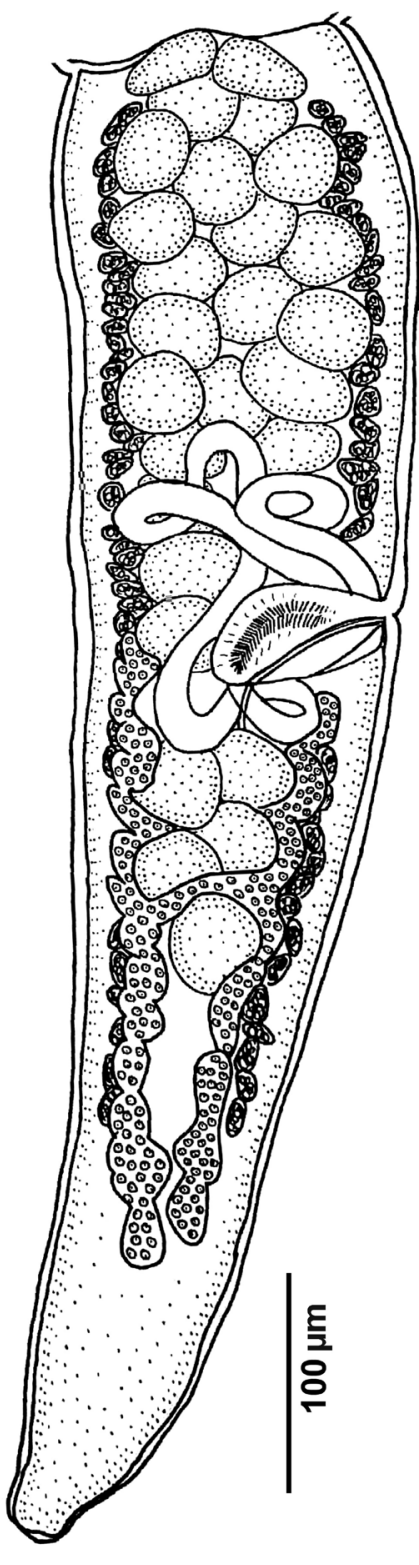

Fig. 2. Line drawing of Acanthobothrium microhabentes sp. n. A - entire specimen; B - scolex; C - mature proglottid; D - hooks.

in total number, 4-7 in postporal field, 1-2 in postovarian field. Cirrus-sac ovoid, bent posteriorly, 57-80 long by 3247 wide, containing armed cirrus; cirrus greatly expanded at base.

Vagina narrow, relatively thin-walled and straight proximally, extending from ootype along medial line of proglottid to posterior margin of cirrus-sac, then laterally to common genital atrium. Ovary takes up approximately half proglottid length, stopping short of posterior margin of proglottid, H-shaped in dorsoventral view, lobulated. Ovary asymmetrical, poral lobe $243-444$ in length, aporal lobe 210-525 in length, both lobes stopping before cirrus-sac; width of ovary at level of ovarian isthmus 54-76; ovarian isthmus located slightly posterior to mid-level of poral lobe of ovary. Mehlis' gland posterior to ovarian isthmus.
Vitellarium follicular, in form of two lateral bands each consisting of two columns of relatively large follicles; bands extending from posterior margin of anterior-most testes to near posterior margin of ovary, interrupted by vagina and cirrus-sac; vitelline follicles 6-13 long by 10-24 wide. Vitelline follicle length relative to testis length $0.1-$ $0.2: 1$. Uterus thin-walled, extending from ovarian isthmus to near anterior margin of proglottid. Eggs not observed.

Type host: Spotted skate, Raja straeleni (Rajiformes: Rajidae). Type 1 o c a lity: South-eastern Atlantic Ocean off De Kelders (-34.5925, 19.2925), South Africa.

Site of infection: Spiral intestine.

Prevalence of infection: $75 \%$ (six of eight skates examined). 


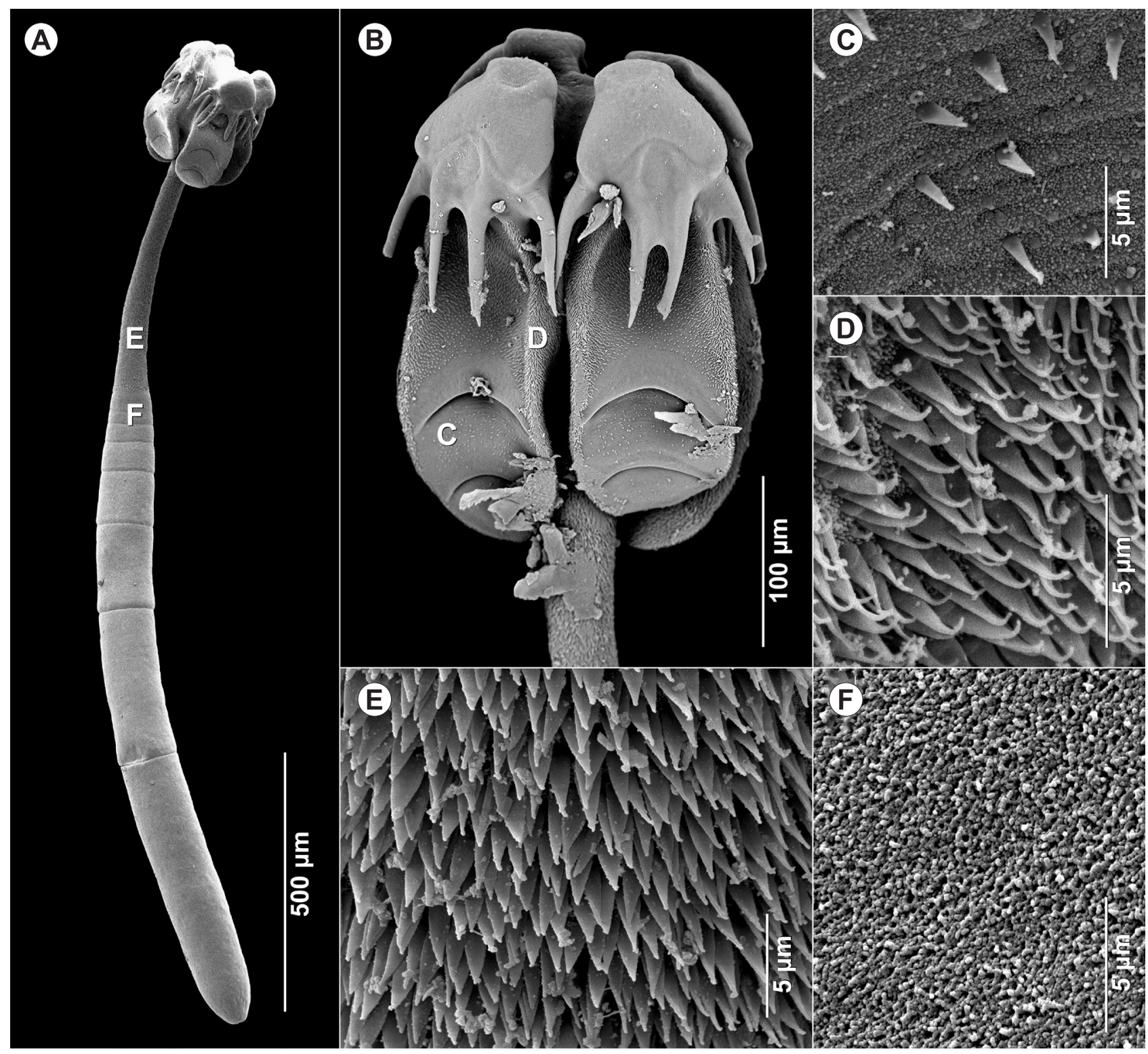

Fig. 3. Scanning electron micrographs of Acanthobothrium microhabentes $\mathrm{sp}$. $\mathrm{n}$. A - entire specimen; letters indicate where micrographs of microtriches were taken; $\mathbf{B}$ - scolex, dorsoventral view; letters indicate where micrographs of microtriches were taken; $\mathbf{C}-$ distal bothridial surface; D - proximal bothridial surface near medial margin of bothridium; $\mathbf{E}$ - cephalic peduncle; $\mathbf{F}$ - first proglottid.

Type materia 1: Holotype deposited at NMB (P-604), paratypes in NMB (P-605-P-606), IPCAS (C-848) and MHNG (PLAT-137324, 137334).

Etymology: The species name "microhabentes" is derived from Latin ("micro", small; "habentes", stumpy) and relates to the small size of the specimens.

Remarks. Acanthobothrium microhabentes sp. n. is identified as a category 2 species according to specifications set by Ghoshroy and Caira (2001). At present, 47 species of Acanthobothrium recognised as category 2 species were reported worldwide (Maleki et al. 2013, Yang et al. 2016, Zaragoza-Tapia et al. 2019, 2020). Additionally, Franzese and Ivanov (2020) recognised two more species belonging to both category 1 and 2 as a result of intraspecific variability observed in ovarian symmetry. For the purpose of a more reliable comparison, the latter is considered as a category 2 species in this study. Acanthobothrium microhabentes fea- tures the presence of testes located posterior to the ovarian isthmus, therefore clearly distinguishing it from 45 of the recognised category 2 species, as well as the additional two species recognised by Franzese and Ivanov (2020).

Only 12 species of Acanthobothrium have been described to bear this unique characteristic feature, from which only two, Acanthobothrium popi Fyler, Caira et Jensen, 2009, and Acanthobothrium bobconniorum Fyler et Caira, 2010, fall into the category 2 (Fyler et al. 2009, Fyler and Caira 2010, Maleki et al. 2015). Acanthobothrium microhabentes is morphologically similar to $A$. bobconniorum. However, when comparing the unique trait responsible for associating these species, there are clear differences between $A$. microhabentes, A. bobconniorum and $A$. popi in the number of testes (less than 31 vs 36-49 and 37-50, respectively) and postovarian testes (1-2 vs 6-10 and 7-11, respectively). 
Furthermore, A. microhabentes differs from both $A$. bobconniorum and $A$. popi in the following characteristic features: a shorter body (less than $3 \mathrm{~mm}$ vs 3-5 $\mathrm{mm}$ and 3.9-7.1 mm, respectively), a shorter scolex (less than $306 \mu \mathrm{m} v s$ 387-490 $\mu \mathrm{m}$ and 426-580 $\mu \mathrm{m}$, respectively), a shorter anterior loculus (less than $105 \mu \mathrm{m} v s$ 177-232 $\mu \mathrm{m}$ and 193-282 $\mu \mathrm{m}$, respectively), a shorter middle loculus (less than $48 \mu \mathrm{m} v s$ 55-87 $\mu \mathrm{m}$ and 53-93 $\mu \mathrm{m}$, respectively), a shorter posterior loculus (less than $56 \mu \mathrm{m} v s$ 62-110 $\mu \mathrm{m}$ and $67-130 \mu \mathrm{m}$, respectively), a narrower accessory sucker (less than $45 \mu \mathrm{m} v s$ 50-56 $\mu \mathrm{m}$ and 50-88 $\mu \mathrm{m}$, respectively), fewer proglottids (less than 9 vs 10-14 and 1420 , respectively), a shorter cirrus-sac (less than $80 \mu \mathrm{m} v \mathrm{~s}$ $120-150 \mu \mathrm{m}$ and $108-152 \mu \mathrm{m})$, and a narrower cirrus-sac (less than $47 \mu \mathrm{m} v s$ 60-117 $\mu \mathrm{m}$ and $70-138 \mu \mathrm{m}$ ).

\section{Acanthobothrium microtenuis sp. $\mathbf{n}$.}

Figs. 4, 5

ZooBank number for species:

urn: 1sid: zoobank.org: act: B578A547-CB56-420E-9382-9B7F1422F9E9

Description (based on 14 whole mounts, nine mature and five immature worms; three mature worms used for SEM observations): Worms 1.6-4.1 mm long; greatest width at level of scolex; 11-18 proglottids per worm; euapolytic. Scolex consisting of scolex proper and longer cephalic peduncle. Scolex proper with four bothridia, 311-318 long by 237-278 wide. Bothridia free posteriorly, 109-134 wide; each with three loculi and specialised anterior region in form of muscular pad. Muscular pad 64-76 long by $105-115$ wide, falciform in shape, with pronounced posterior margin, bearing accessory sucker and one pair of hooks at posterior margin; accessory sucker 38-43 long by 44-45 wide. Anterior loculus (A) 130-150 long; middle loculus (M) 47-56 long; posterior loculus (P) 59-68 long; loculus length ratio (A : $\mathrm{M}: \mathrm{P}) 1: 2.7: 2.2$; maximum width of scolex at level of middle loculus. Velum absent.

Hooks bi-pronged, hollow, with tubercle on proximal surface of axial prong; internal channels of axial and abaxial prongs continuous, smooth; axial prongs slightly longer than abaxial prongs; lateral and medial hooks approximately equal in size. Lateral hook measurements: A 40-52, B 69-97, C 54-94, D 105-135. Medial hook measurements: A' 41-54, B' 72-82, C' 69-89, D’ 114-134. Bases of lateral and medial hooks approximately equal in length; base of lateral hooks slightly overlapping base of medial hooks along medial axis of bothridium (Fig. 4D); lateral hook base slightly wider than medial hook base. Thin layer of tissue covering essentially entire length of each prong of hooks. Long cephalic peduncle $695-1,858$ long by $56-68$ wide.

Apical pad and distal bothridial surface covered with papilliform filitriches and sparsely interspersed gladiate spinitriches (Fig. 5D). Proximal bothridial surface covered with gladiate spinitriches, sparsely interspersed with papilliform filitriches (Fig. 5E); papilliform filitriches pronounced along bothridial rims (Fig. 5E). Cephalic peduncle densely covered with gladiate spinitriches (Fig. 5F). Papilliform filitriches pronounced on strobila (Fig. 5G). Anterior part of terminal proglottid with prominent columnar spinitriches (Fig. 5H).
Proglottids acraspedote. Immature proglottids $8-18$ in number; mature proglottids $1-2$ in number; gravid proglottids absent; terminal proglottid 639-1,065 long by 134-211 wide; terminal proglottid length to width ratio $3.2-7.5: 1$. Proglottids protandrous; genital pores marginal, irregularly alternating, 58-64\% of proglottid length from posterior end; testes conspicuous in mature proglottids, irregularly oval in dorsoventral view, 44-64 long by 25-41 wide, arranged in two regular columns, one layer deep, 24-33 in total number, 6-8 in postporal field, $1-2$ in postovarian field. Cirrus-sac elongate, straight, 112-126 long by 48-72 wide, containing armed cirrus; cirrus greatly expanded at base.

Vagina narrow, relatively thin-walled and coiled proximally, greatly expanded distally, extending from ootype along medial line of proglottid to anterior margin of cirrus-sac, then laterally along anterior margin of cirrus-sac to common genital atrium. Ovary takes up approximately half of proglottid length, stopping short of posterior margin of proglottid, H-shaped in dorsoventral view, lobulated. Ovary asymmetrical, poral lobe $340-523$ in length, aporal lobe 350-610 in length, both lobes extending past cirrus-sac; width of ovary at ovarian isthmus 95-116; ovarian isthmus located slightly posterior to mid-level of poral lobe of ovary. Mehlis' gland posterior to ovarian isthmus.

Vitellarium follicular, in form of two lateral bands, each consisting of two columns of relatively large follicles; bands extending from posterior margin of anterior-most testes to near posterior margin of ovary, interrupted by vagina and cirrus-sac; vitelline follicles 11-21 long by 2034 wide. Vitelline follicle length relative to testes length $0.2-0.3: 1$. Uterus thin-walled, sacciform, extending from ovarian isthmus to near anterior margin of proglottid. Eggs not observed.

Type host: Spotted skate, Raja straeleni (Rajiformes: Rajidae).

Type 1 o c a lity: South-eastern Atlantic Ocean off De Kelders (-34.5925, 19.2925), South Africa.

Site of infection: Spiral intestine.

Prevalence of infection: $88 \%$ (seven of eight skates observed).

Type material: Holotype deposited at NMB (P-607), paratypes in NMB (P-608-P-609), IPCAS (C-849) and MHNG (PLAT-137335, 137340).

E t y m o log y: The species name "microtenuis" is derived from Latin ("micro", small; "tenuis", slender) and relates to the small and slender body shape of specimens.

Remarks. Acanthobothrium microtenuis sp. n., as a category 2 species, differs from all except three of the category 2 species, along with those described from Franzese and Ivanov (2020), in its possession of postovarian testes. It resembles $A$. bobconniorum, $A$. microhabentes sp. n. and $A$. popi morphologically but differs from these three species by its possession of an elongate cephalic peduncle (exceeding $700 \mu \mathrm{m} v s$ 212-650 $\mu \mathrm{m}, 352-695 \mu \mathrm{m}$, and 328-450 $\mu \mathrm{m}$, respectively). When comparing the length of the cephalic peduncle relative to the total body length for each species, the distinct individuality of $A$. microtenuis becomes even 


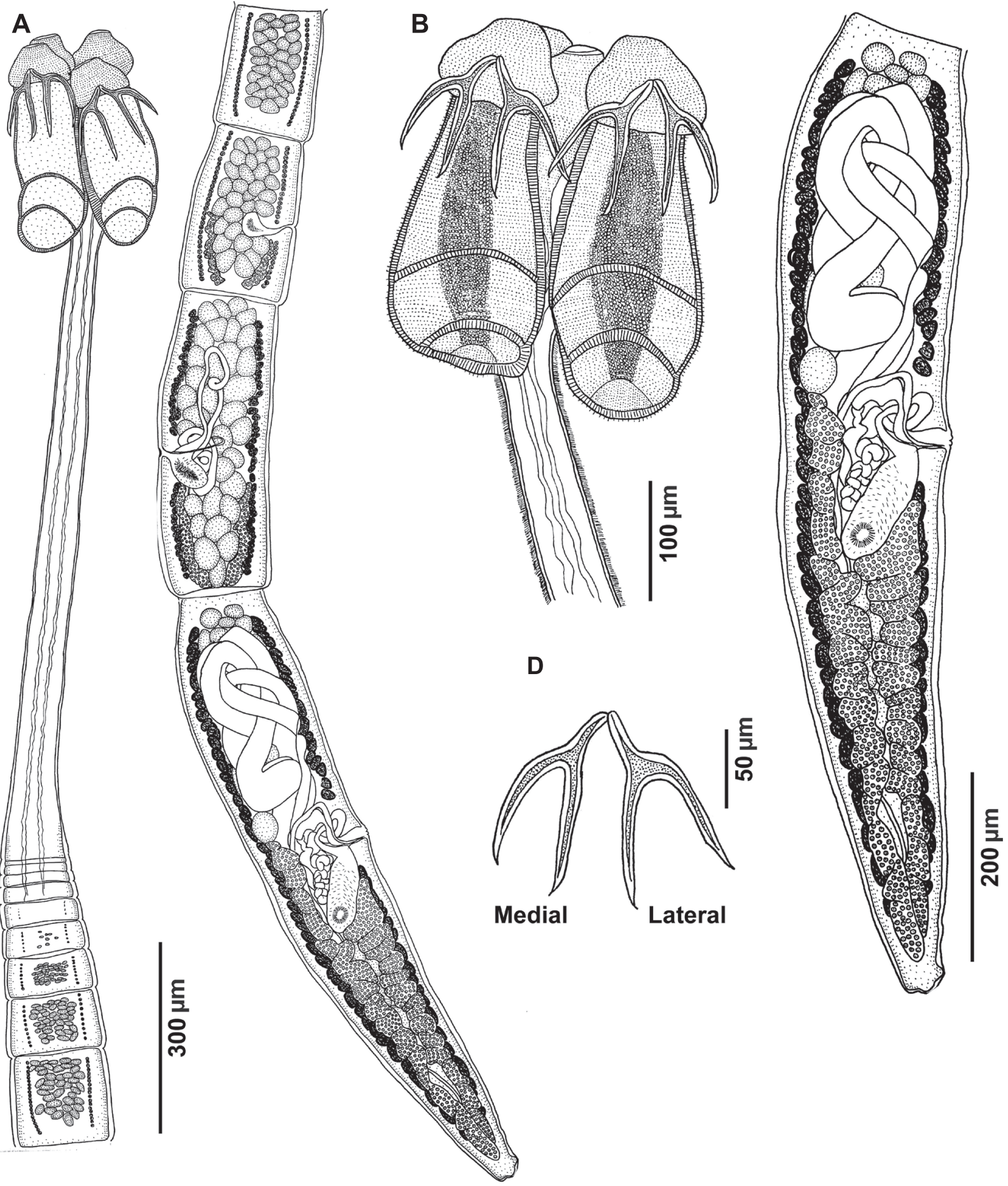

Fig. 4. Line drawing of Acanthobothrium microtenuis sp. n. A - entire specimen; B - scolex; C-mature proglottid; $\mathbf{D}$ - hooks.

more prominent, as the cephalic peduncle equates $1 / 3$ of the total length, whereas in A. bobconniorum and A. popi, the cephalic peduncle equates to $1 / 8$ and $1 / 16$ relative to the total body length, respectively. Apart from the cephalic peduncle, additional morphological differences between $A$. microtenuis, A. bobconniorum and $A$. popi can be observed in the following characteristic features: fewer testes (less than 33 vs 36-49 and 37-50, respectively), fewer postovarian testes (1-2 vs 6-10 and 7-11, respectively), a shorter scolex (less than $306 \mu \mathrm{m} v s$ 387-490 $\mu \mathrm{m}$ and 426-580 $\mu \mathrm{m}$, respectively), a shorter anterior loculus (less than $150 \mu \mathrm{m}$ vs 177-232 $\mu \mathrm{m}$ and 193-282 $\mu \mathrm{m}$, respectively), a shorter muscular pad (less than $76 \mu \mathrm{m} v s$ 76-110 $\mu \mathrm{m}$ and 88-118 $\mu \mathrm{m}$, respectively), and a narrower accessory sucker (less than $45 \mu \mathrm{m} v s$ 50-65 $\mu \mathrm{m}$ and 50-88 $\mu \mathrm{m}$, respectively).

Acanthobothrium microtenuis differs from A. microhabentes by a longer anterior loculus (exceeding $130 \mu \mathrm{m}$ vs 99-105 $\mu \mathrm{m}$ ), a longer posterior loculus (exceeding 60 $\mu \mathrm{m} v s$ 48-56 $\mu \mathrm{m})$, greater number of proglottids (11-18 vs 5-9), a longer cirrus-sac (exceeding $112 \mu \mathrm{m} v s$ 57-80 $\mu \mathrm{m}$ ), and a wider ovary (exceeding $95 \mu \mathrm{m} v s$ 54-76 $\mu \mathrm{m}$ ). One additional morphological characteristic of $A$. microtenuis, 


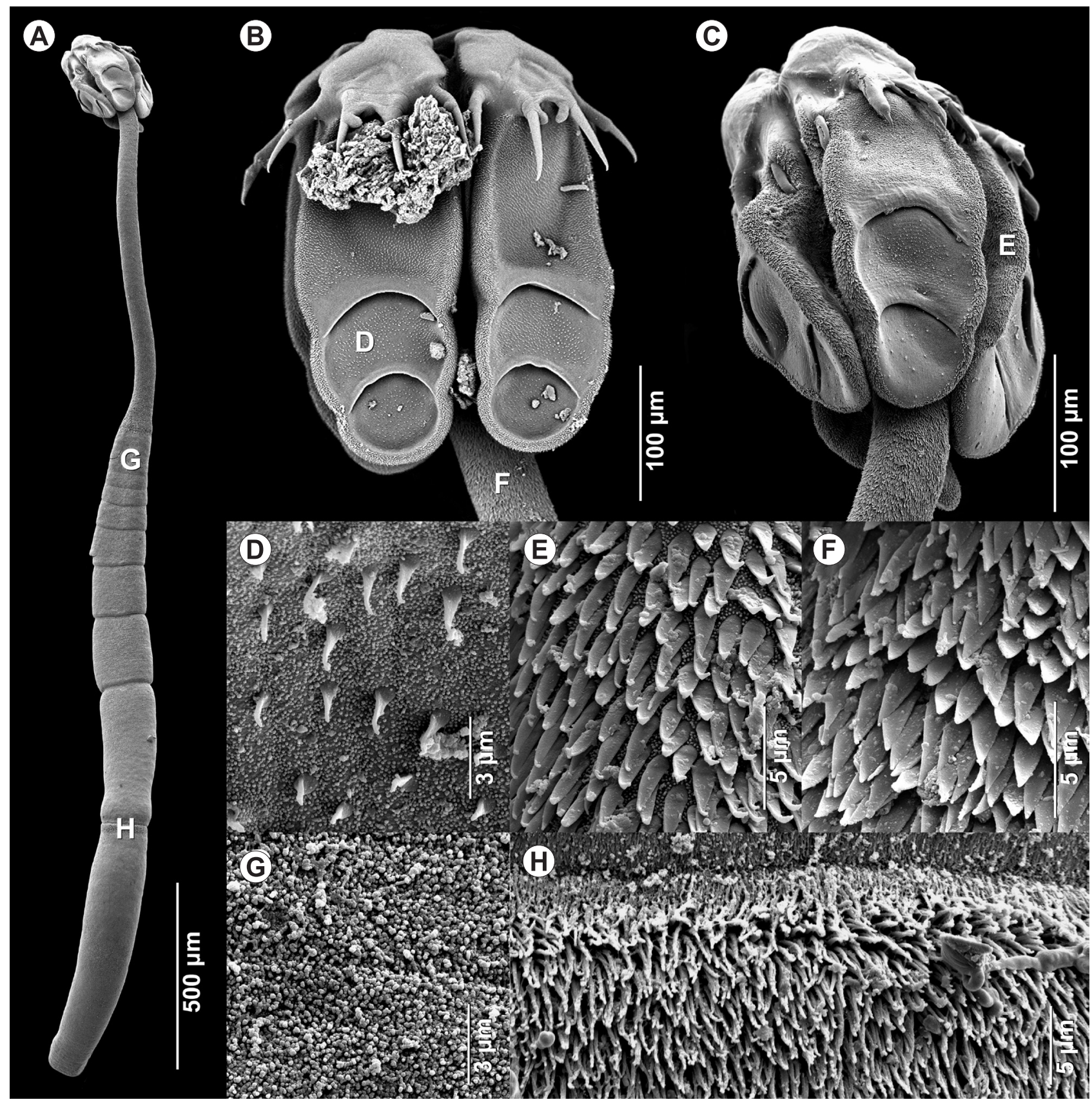

Fig. 5. Scanning electron micrographs of Acanthobothrium microtenuis sp. n. A - entire specimen; letters indicate where micrographs of microtriches were taken; B - scolex, dorsoventral view; letters indicate where micrographs of microtriches were taken; $\mathbf{C}$ - scolex, lateral view; letter indicates where micrograph of microtriches was taken; D - distal bothridial surface; $\mathbf{E}$ - proximal bothridial surface near medial margin of bothridium; F - cephalic peduncle; $\mathbf{G}$ - first proglottid; $\mathbf{H}$ - anterior region of terminal proglottid.

contributing to the validity of this species, is the presence of columnar spinitriches observed on the anterior margin of the terminal proglottid (Fig. 5H). This feature has not been reported for any of the three congeners before.

\section{Acanthobothrium crassus sp. n.}

Figs. 6, 7

\section{ZooBank number for species:}

urn: 1sid: zoobank.org: act: D08145EC-E8B2-4FBD-9B40-3A66BEF3E45C

Description (based on five whole mounts, five mature worms; two mature worms used for SEM observations): Worms 5.6-8.1 mm long; greatest width at level of scolex; 27-33 proglottids per worm; euapolytic. Scolex consisting of scolex proper and long cephalic peduncle. Scolex proper with four bothridia, 442-450 long by 318-337 wide. Bothridia free posteriorly, $138-173$ wide; each with three loculi and specialised anterior region in form of muscular pad. Muscular pad 91-102 long by 102-108 wide, falciform in shape, with pronounced posterior margin, bearing accessory sucker and one pair of hooks at posterior margin; accessory sucker 40-46 long by 44-49 wide. Anterior loculus (A) 175-185 long; middle loculus (M) 76-88 long; posterior loculus $(\mathrm{P})$ 77-85 long; loculus length ratio (A : $\mathrm{M}: \mathrm{P})$ $1: 2.2: 2.2$; maximum width of scolex at level of middle loculus. Velum absent. 


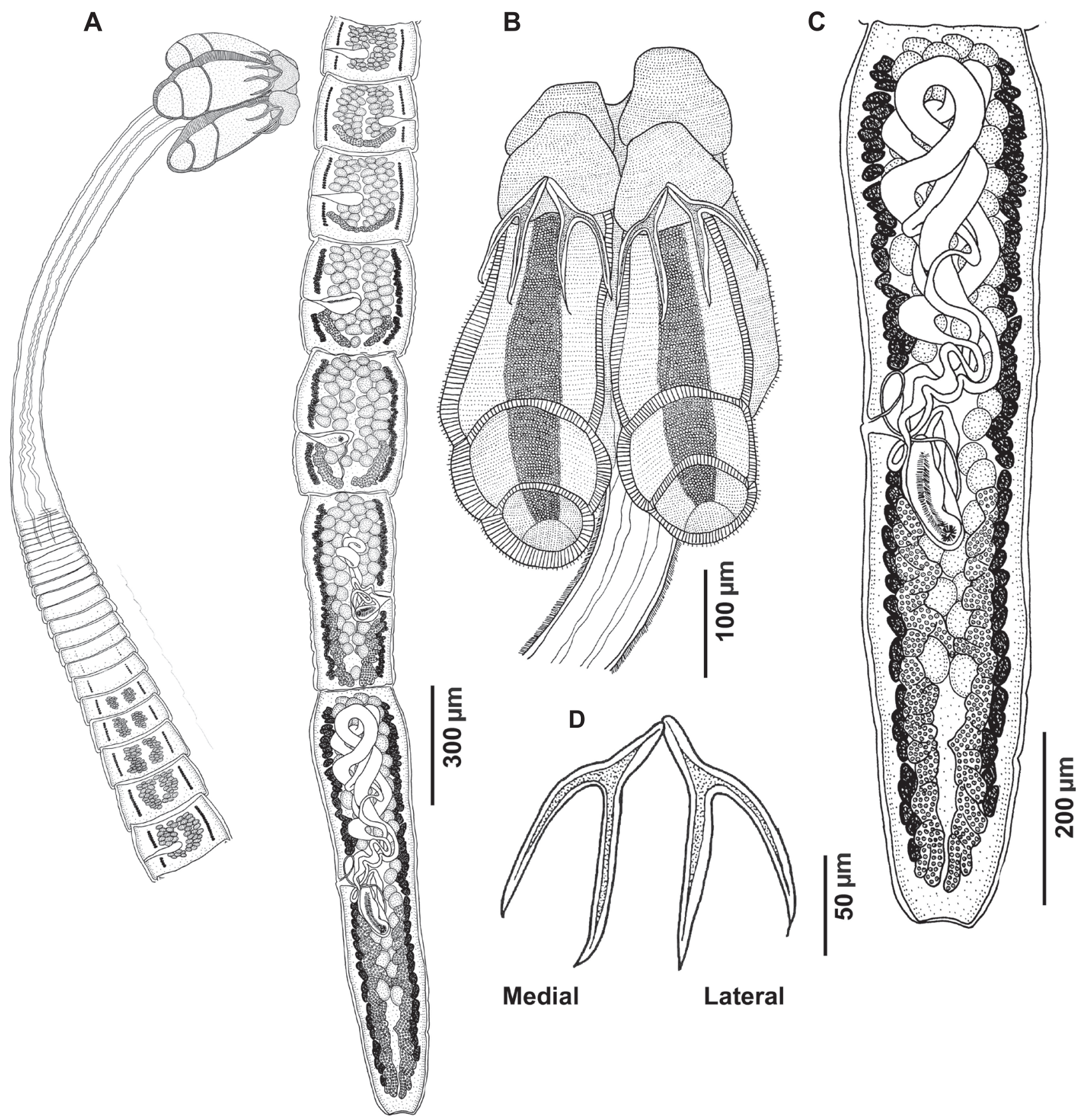

Fig. 6. Line drawing of Acanthobothrium crassus sp. n. A - entire specimen; B - scolex; C - mature proglottid; D - hooks.

Hooks bi-pronged, hollow, with tubercle on proximal surface of axial prong; internal channels of axial and abaxial prongs continuous, smooth; axial prongs slightly longer than abaxial prongs; lateral and medial hooks approximately equal in size. Lateral hook measurements: A 42-48, B 72-85, C 62-75, D 106-118. Medial hook measurements: A' 40-46, B' 71-89, C' 66-80, D' 107-126. Bases of lateral and medial hooks approximately equal in length; base of lateral hooks slightly overlapping base of medial hooks along medial axis of bothridium (Fig. 6D); lateral hook base slightly wider than medial hook base. Thin layer of tissue covering essentially entire length of each prong of hooks. Long cephalic peduncle 1,331-2,009 long by 88-94 wide.
Apical pad and distal bothridial surfaces covered with papilliform filitriches and sparsely interspersed gladiate spinitriches (Figs. 7C, D). Proximal bothridial surfaces covered with aristate gladiate spinitriches interspersed with acicular filitriches (Fig. 7E); capilliform filitriches pronounced along bothridial rims. Cephalic peduncle densely covered with gladiate spinitriches (Fig. 7F). Capilliform filitriches pronounced on strobila (Fig. 7G).

Proglottids craspedote. Immature proglottids 25-30 in number; mature proglottids $1-3$ in number; gravid proglottids absent; terminal proglottid 980-1,285 long by 138-173 wide; terminal proglottid length to width ratio 4-7.5 : 1 . Proglottids protandrous; genital pores marginal, irregularly alternating, $54-63 \%$ of proglottid length from posterior end. 


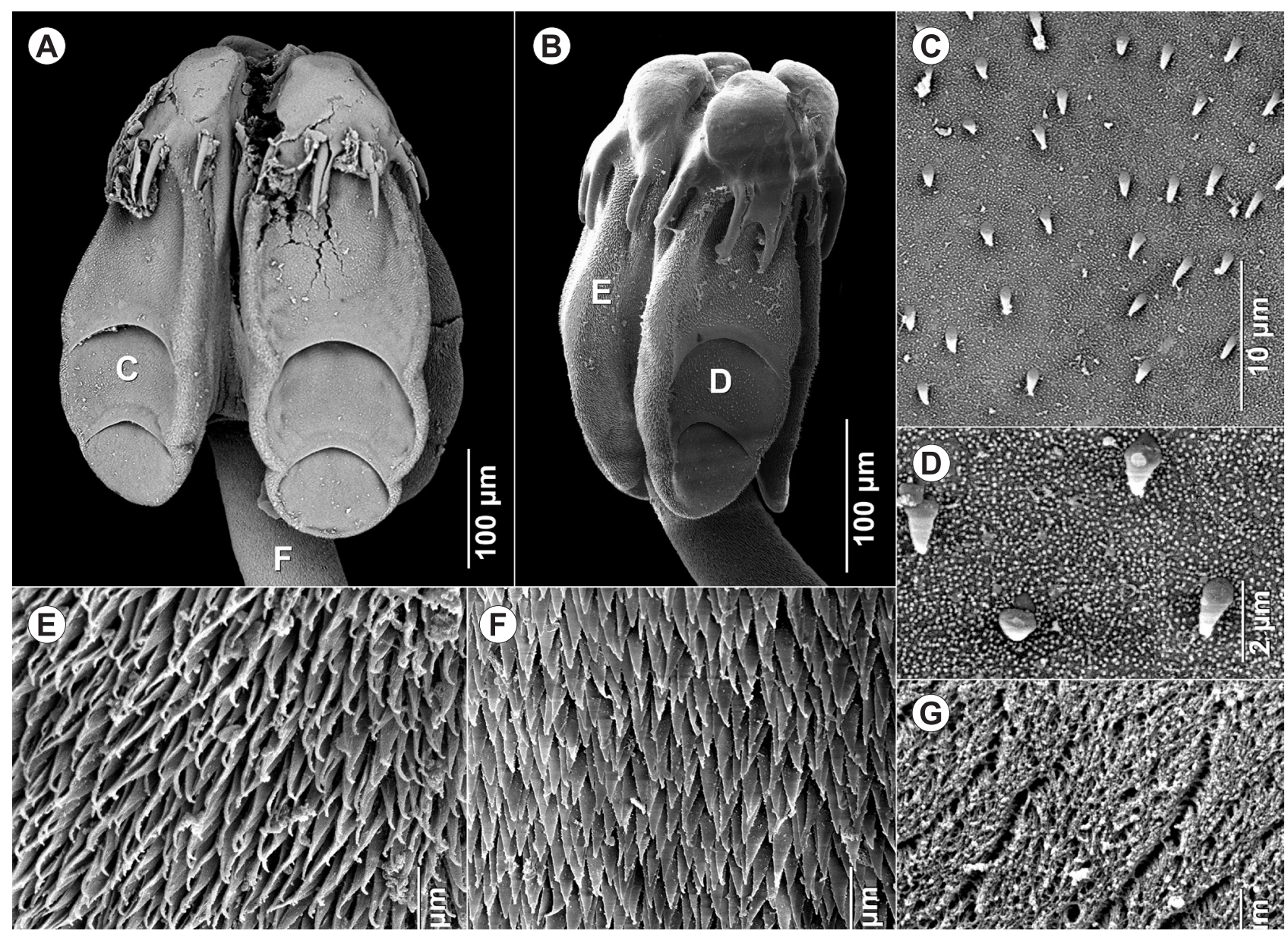

Fig. 7. Scanning electron micrographs of Acanthobothrium crassus sp. n. A-scolex, dorsoventral view; letters indicate where micrographs of microtriches were taken; $\mathbf{B}$ - scolex, lateral view; letters indicate where micrographs of microtriches were taken; $\mathbf{C}-$ distal bothridial surface; D - detailed view of distal bothridial surface; $\mathbf{E}$ - proximal bothridial surface near medial margin of bothridium; $\mathbf{F}$ - cephalic peduncle; $\mathbf{G}$ - anterior strobila.

Testes conspicuous in mature proglottids, irregularly oval in dorsoventral view, $45-54$ long by $36-43$ wide, arranged in two regular columns, one layer deep, 40-46 in total number, $8-10$ in postporal field, $1-3$ in postovarian field. Cirrus-sac elongate, bent posteriorly, 123-133 long by $48-55$ wide, containing armed cirrus; cirrus greatly expanded at base.

Vagina narrow, relatively thin-walled and coiled proximally, greatly expanded distally, extending from ootype along medial line of proglottid to anterior margin of cirrus-sac, then laterally to common genital atrium. Ovary takes up approximately half of proglottid, stopping short of posterior margin of the proglottid, $\mathrm{H}$-shaped in dorsoventral view, lobulated. Ovary asymmetrical, poral lobe 440-652 in length, aporal lobe 464-711 in length; both lobes extending shortly past cirrus-sac; width of ovary at ovarian isthmus 98-115; ovarian isthmus located slightly posterior to midpoint of poral lobe of ovary. Mehlis' gland posterior to ovarian isthmus.

Vitellarium follicular, in form of two lateral bands, each consisting of two columns of relatively large follicles; bands extending from posterior margin of anterior-most testes to near posterior margin of ovary, interrupted by vagina and cirrus-sac; vitelline follicles $12-19$ long by $32-$
38 wide. Vitelline follicle length relative to testes length $0.2-0.3: 1$. Uterus thin-walled, sacciform, extending from ovarian isthmus to near anterior margin of proglottid. Eggs not observed.

Type host: Spotted skate, Raja straeleni (Rajiformes: Rajidae).

Ty p e 1 o c a lit y: South-eastern Atlantic Ocean off De Kelders (-34.5925, 19.2925), South Africa.

Site of infection: Spiral intestine.

Prevalence of infection: $38 \%$ (three of eight skates examined).

Type material: Holotype deposited at NMB (P-610), paratypes in NMB (P-611), IPCAS (C-850) and MHNG (PLAT137341).

Etymology: The species name "crassus" is derived from Latin ("crassus", thick) and relates to the form of proglottids, which are considerably thicker in comparison to congeners from South Africa.

Remarks. Acanthobothrium crassus sp. n. following the classification criteria set by Ghoshroy and Caira (2001), is identified as a category 2 species. By including both $A$. microhabentes sp. n. and $A$. microtenuis sp. n., $A$. crassus is among the 50th category 2 species reported to 
date. Acanthobothrium crassus differs from all but four of its congeners in the possession of postovarian testes. Acanthobothrium crassus is distinguished from A. bobconniorum, A. microhabentes, A. microtenuis, and A. popi by a combination of morphological features. One such feature is the presence of craspedote proglottids in A. crassus, whereas its congeners possess acraspedote proglottids.

Acanthobothrium crassus has a larger body composed of more proglottids (i.e. 27-33), in comparison to congeners with a smaller body not exceeding 20 proglottids. In addition, the new species differs from $A$. microhabentes and $A$. microtenuis in the following characteristic features: a larger body (exceeding $6 \mathrm{~mm} v s \quad 1.5-3 \mathrm{~mm}$ and 1.6-4.1 $\mathrm{mm}$, respectively), a larger scolex (exceeding $442 \mu \mathrm{m} \times$ $320 \mu \mathrm{m} v s$ 301-306 $\mu \mathrm{m} \times 215-248 \mu \mathrm{m}$ and 311-318 $\mu \mathrm{m} \times$ 237-278 $\mu \mathrm{m}$, respectively), a wider bothridium (exceeding $140 \mu \mathrm{m} v s$ 105-115 $\mu \mathrm{m}$ and 109-134 $\mu \mathrm{m}$, respectively), a longer muscular pad (exceeding $90 \mu \mathrm{m} v s$ 63-74 $\mu \mathrm{m}$ and 64-76 $\mu \mathrm{m}$, respectively), and a greater number of testes (exceeding 40 vs 21-31 and 24-33, respectively). The cephalic peduncle is considerably longer in A. crassus (exceeding $1,330 \mu \mathrm{m}$ ) than the one of $A$. bobconniorum (212-650 $\mu \mathrm{m})$, A. microhabentes (352-695 $\mu \mathrm{m})$ and $A$. popi $(328-450 \mu \mathrm{m})$.

Additionally, A. crassus differs from A. bobconniorum

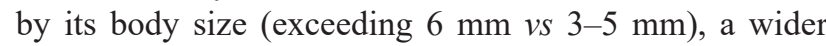
scolex (exceeding $320 \mu \mathrm{m} v s$ 215-282 $\mu \mathrm{m}$, respectively), a narrower cirrus-sac (less than $55 \mu \mathrm{m} v s$ 60-117 $\mu \mathrm{m}$, respectively), less postovarian testes (3vs 6-10, respectively), longer testes (exceeding $45 \mu \mathrm{m} v s$ 17-45 $\mu \mathrm{m}$, respectively), and much wider vitelline follicles (exceeding 32 $\mu \mathrm{m} v s$ 12-25 $\mu \mathrm{m}$, respectively).

Acanthobothrium crassus is morphologically similar to A. popi, but differs from the latter by having a narrower muscular pad (less than $108 \mu \mathrm{m} v s$ 112-163 $\mu \mathrm{m}$, respectively), a shorter lateral hook $\mathrm{C}$ (less than $75 \mu \mathrm{m}$ vs 75-100 $\mu \mathrm{m}$, respectively), a shorter medial hook C' (less than 80 $\mu \mathrm{m} v s$ 87-108 $\mu \mathrm{m}$, respectively), a narrower cirrus-sac (less than $55 \mu \mathrm{m} v s$ 70-138 $\mu \mathrm{m}$, respectively), fewer postovarian testes (1-3vs 7-11, respectively), and larger vitelline follicles (exceeding $32 \mu \mathrm{m} v s$ 13-25 $\mu \mathrm{m}$, respectively).

\section{Acanthobothrium dolichocollum sp. n.}

Figs. 8, 9

ZooBank number for species:

urn: 1sid: zoobank.org: act: 89F7BDDD-8036-4F56-B366-C96712CE1291

Description (based on six whole mounts, six mature worms; two mature worms used for SEM observations): Worms 7.7-10.5 mm long; greatest width at level of scolex; 30-46 proglottids per worm; euapolytic. Scolex consisting of scolex proper and extremely long cephalic peduncle. Scolex proper with four bothridia, 410-416 long by 344-360 wide. Bothridia free posteriorly, 126-134 wide; each with three loculi and specialised anterior region in form of a muscular pad. Muscular pad 77-84 long by 120-126 wide, falciform in shape, with pronounced posterior margin, bearing accessory sucker and one pair of hooks at posterior margin; accessory sucker 48-51 long by 51-56 wide. Anterior loculus (A) 175-202 long; middle loculus (M) 75-86 long; posterior loculus (P) 61-71 long; loculus length ratio (A: M: P) $1: 2.3: 2.8$; maximum width of scolex at level of middle loculus. Velum absent.

Hooks bi-pronged, hollow, with tubercle on proximal surface of axial prong; internal channels of axial and abaxial prongs continuous, smooth; axial prongs slightly longer than abaxial prongs; lateral and medial hooks approximately equal in size. Lateral hook measurements: A 35-47, B 68-76, C 51-68, D 95-112. Medial hook measurements: A' 42-46, B' 61-74, C' 59-73, D' 98-116. Bases of lateral and medial hooks approximately equal in length; base of lateral hooks slightly overlapping base of medial hooks along medial axis of bothridium (Fig. 8D); lateral hook base slightly wider than medial hook base. Thin layer of tissue covering essentially entire length of each prong of hooks. Extremely long cephalic peduncle 2.07-4.78 long by 66-73 wide.

Apical pad and distal bothridial surfaces covered with sparsely interspersed gladiate spinitriches (Fig. 9C). Proximal bothridial surfaces covered with gladiate spinitriches interspersed with capilliform filitriches (Fig. 9D); acicular filitriches prominent along bothridial rims. Cephalic peduncle densely covered with gladiate spinitriches (Fig. 9E). Strobila covered with papilliform filitriches (Fig. 9F). Anterior margin of terminal proglottid covered with acicular filitriches (Fig. 9G).

Proglottids acraspedote. Immature proglottids 28-44 in number; mature proglottids $2-4$ in number; gravid proglottids absent; terminal proglottid 1,046-1,484 long by 182-260 wide; terminal proglottid length to width ratio 3.9-10.7 : 1. Proglottids protandrous; genital pores marginal, irregularly alternating, $56-66 \%$ of proglottid length from posterior end.

Testes conspicuous in mature proglottids, irregularly oval in dorsoventral view, 52-60 long by 41-49 wide, arranged in two regular columns, one layer deep, 33-39 in total number, 10-13 in postporal field, 2-4 in postovarian field. Cirrus-sac pyriform, bent anteriorly, 122-127 long by $68-72$ wide, containing armed cirrus; cirrus greatly expanded at base.

Vagina narrow, relatively thin-walled and extensively coiled proximally, thick-walled and greatly expanded distally, extending from ootype along medial line of proglottid to anterior margin of cirrus-sac, then laterally along anterior margin of cirrus-sac to common genital atrium. Ovary takes up almost half of length of proglottid, stopping short of posterior margin of proglottid, H-shaped in dorsoventral view, lobulated. Ovary asymmetrical, poral lobe 538-692 in length, aporal lobe 565-689 in length, both lobes extending past cirrus-sac; width of ovary at ovarian isthmus 108-120; ovarian isthmus located slightly posterior to mid-level of poral lobe of ovary. Mehlis' gland posterior to ovarian isthmus.

Vitellarium follicular, in form of two lateral bands, each consisting of two columns of relatively large follicles; bands extending from posterior margin of anterior-most testis to near posterior margin of ovary, interrupted by vagina and cirrus-sac; vitelline follicles 17-23 long by 3441 wide. Vitelline follicle length relative to testes length $0.3-0.4: 1$. Uterus thin-walled, sacciform, extending from 
A

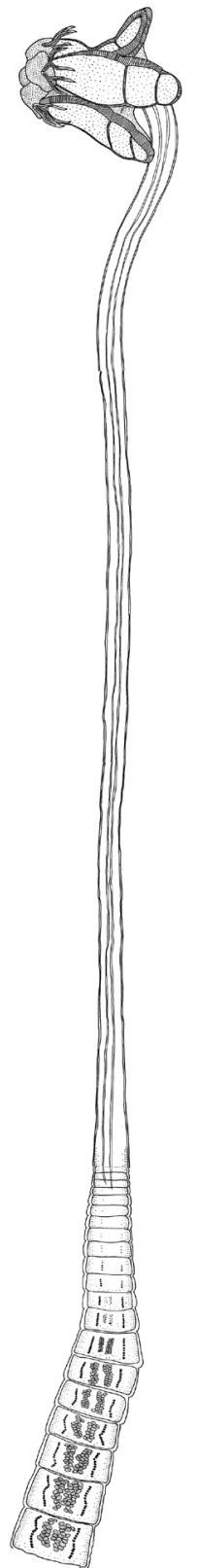

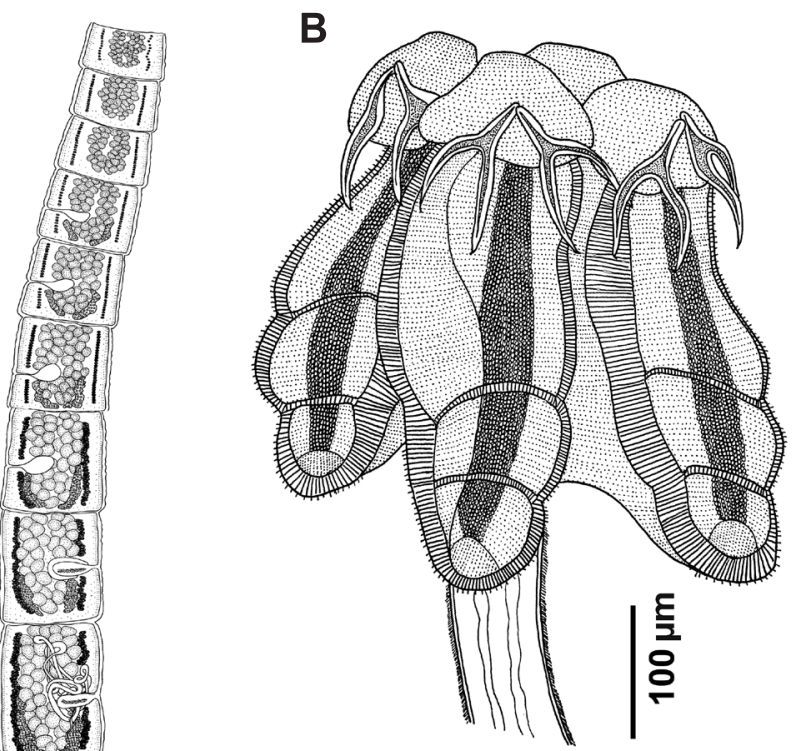

B
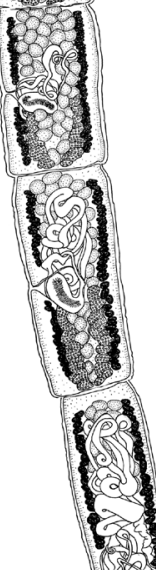

a

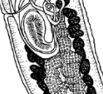

(1)
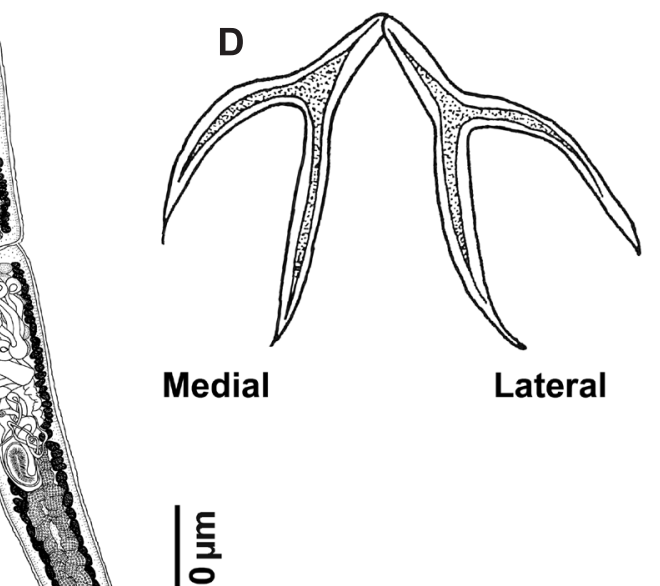

Medial

Lateral
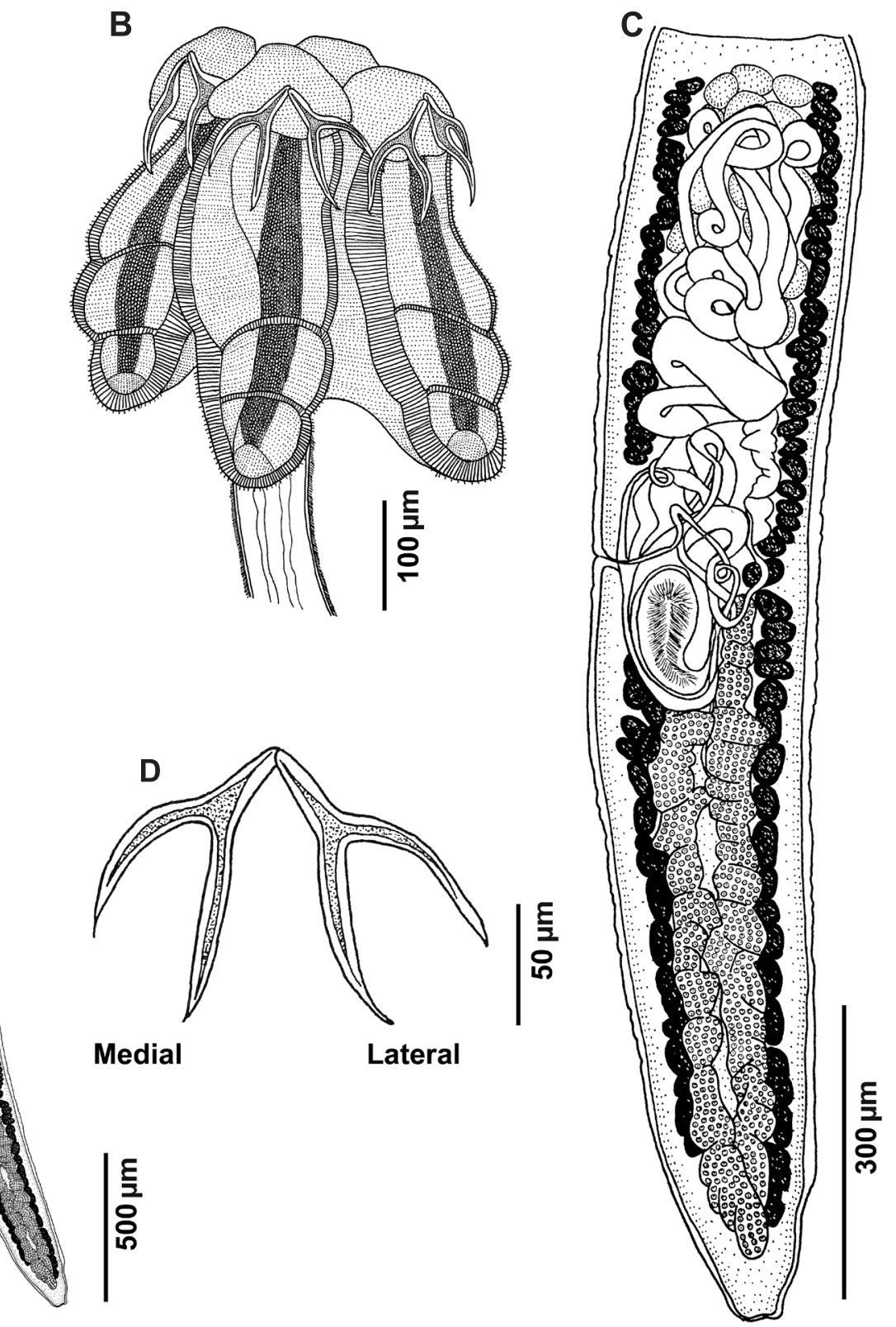

Fig. 8. Line drawing of Acanthobothrium dolichocollum sp. n. A - entire specimen; B - scolex; C - mature proglottid; D - hooks.

ovarian isthmus to near anterior margin of proglottid. Eggs not observed.

Type host: Spotted skate, Raja straeleni (Rajiformes: Rajidae).

Type 1 oc ality: South-eastern Atlantic Ocean off Hermanus $(-34.6355,19.4933)$, South Africa.

Site of infection: Spiral intestine.

Prevalence of infection: 50\% (four of eight skates observed).

Type materia 1: Holotype deposited at NMB (P-612), paratypes in NMB (P-613), IPCAS (C-851) and MHNG (PLAT137342, 137343).

Etymology: The species name "dolichocollum" is derived from Latin ("dolicho", elongate; "collum", neck) and relates to the unique morphological characteristic of the species i.e., its elongate cephalic peduncle.
Remarks. Acanthobothrium dolichocollum sp. n., following the classification criteria set by Ghoshroy and Caira (2001), is identified as a category 2 species. With the description of $A$. dolichocollum, we now recognise 51 species of Acanthobothrium assigned to category 2. Acanthobothrium dolichocollum presents testes located posterior to the ovarian isthmus, differentiating it from 45 of the recognised category 2 species, as well as the two additional species described by Franzese and Ivanov (2020). Acanthobothrium dolichocollum differs from the remaining five category 2 species, A. bobconniorum, A. popi, A. microhabentes sp. n., A. microtenuis sp. n. and A. crassus sp. n., by having more postporal testes (exceeding 10 vs 6-10, 5-9, 4-7, 6-8, and 8-10, respectively).

Another truly exceptional feature of $A$. dolichocollum is the possession of an extraordinarily long cephalic peduncle (exceeding $2 \mathrm{~mm}$ ), equivalent to $1 / 3$ of its total 


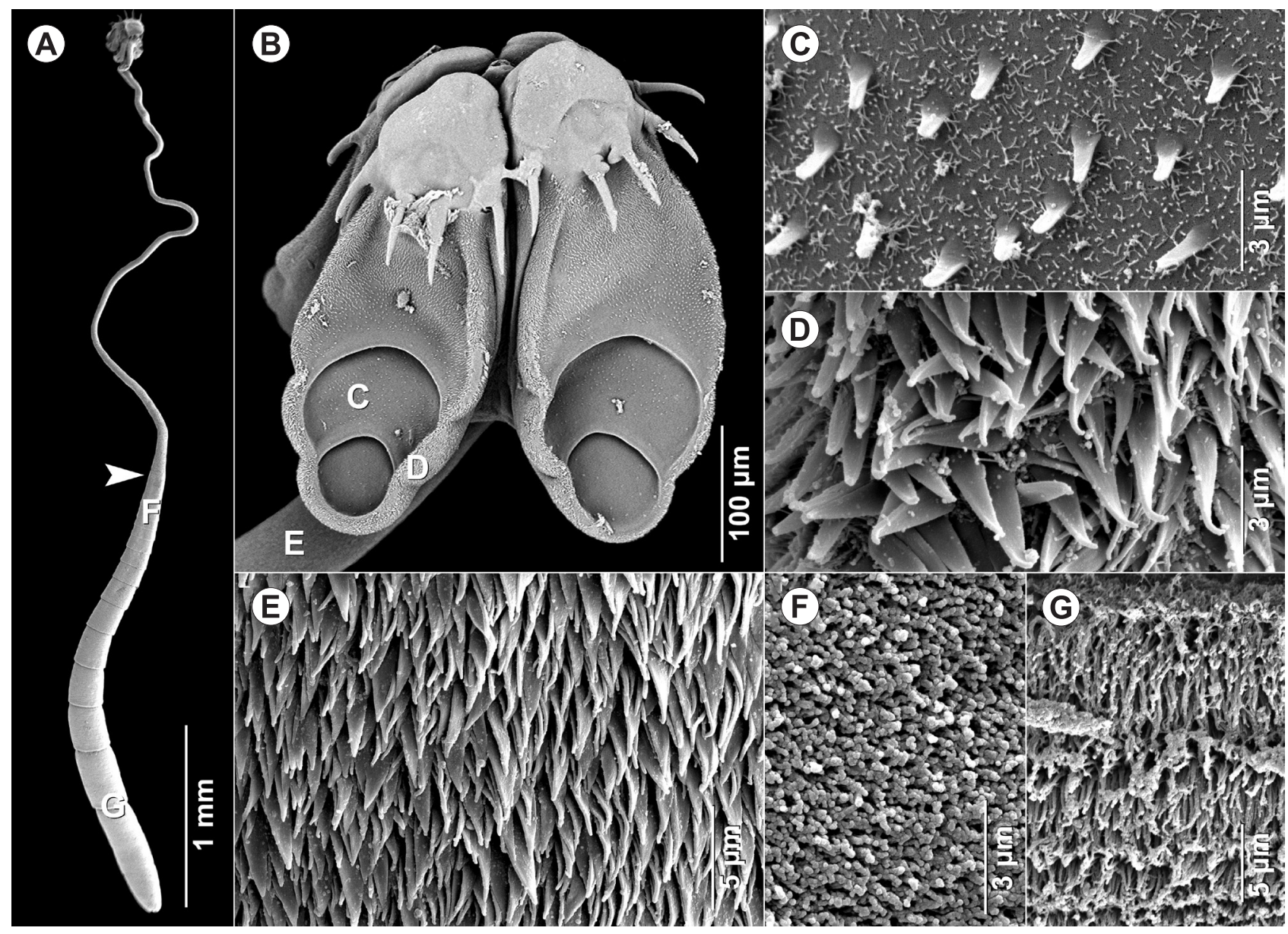

Fig. 9. Scanning electron micrographs of Acanthobothrium dolichocollum sp. $\mathrm{n}$. A - entire specimen; arrow indicates termination of cephalic peduncle, letters indicate where micrographs of microtriches were taken; $\mathbf{B}$ - scolex, dorsoventral view, letters indicate where micrographs of microtriches were taken; $\mathbf{C}$ - distal bothridial surface; $\mathbf{D}$ - proximal bothridial surface near medial margin of bothridium; $\mathbf{E}$ - cephalic peduncle; $\mathbf{F}$ - first proglottid; $\mathbf{G}$ - anterior region of terminal proglottid.

body length. The cephalic peduncle of $A$. bobconniorum and $A$. popi is much shorter $(212-650 \mu \mathrm{m}$ and $328-450$ $\mu \mathrm{m}$, respectively), equivalent to $1 / 8$ and $1 / 17$ of the body length, respectively. Furthermore, $A$. dolichocollum differs from A. bobconniorum, A. popi, A. microhabentes and $A$. microtenuis by having a larger body (exceeding $7.7 \mathrm{~mm} v \mathrm{~s}$ 3-5 mm, 3.9-7.1 mm, 1.5-3 mm and 1.6-4.1 mm, respectively), more proglottids (exceeding 30 vs 10-14, 14-20, 5-9 and 11-18, respectively), and wider vitelline follicles (exceeding $34 \mu \mathrm{m} v s$ 12-25 $\mu \mathrm{m}, 13-25 \mu \mathrm{m}, 10-24 \mu \mathrm{m}$ and 20-34 $\mu \mathrm{m}$, respectively).

Differences between A. dolichocollum, A. microhabentes, A. microtenuis and $A$. crassus can be seen in the scolex length (410-416 $\mu \mathrm{m} v s$ 301-306 $\mu \mathrm{m}, 311-318 \mu \mathrm{m}$ and 442-450 $\mu \mathrm{m}$, respectively), scolex width (344-360 $\mu \mathrm{m}$ vs 215-248 $\mu \mathrm{m}, 237-278 \mu \mathrm{m}$ and 318-337 $\mu \mathrm{m}$, respectively), muscular pad length (77-84 $\mu \mathrm{m}$ vs 63-74 $\mu \mathrm{m}, 64-76$ $\mu \mathrm{m}$ and 91-102 $\mu \mathrm{m}$, respectively), muscular pad width (120-126 $\mu \mathrm{m} v s$ 97-113 $\mu \mathrm{m}, 105-115 \mu \mathrm{m}$ and 102-108 $\mu \mathrm{m}$, respectively), number of testes (33-39 vs 21-31, 24-33 and 40-46, respectively), and testes width (41-49 $\mu \mathrm{m} v s$ 23-35 $\mu \mathrm{m}, 25-41 \mu \mathrm{m}$ and 36-43 $\mu \mathrm{m}$, respectively). Acanthobothrium dolichocollum differs from A. bobconniorum in a wider scolex (exceeding $344 \mu \mathrm{m}$ vs 215-282 $\mu \mathrm{m}$, respectively), smaller lateral hooks (A less than $47 \mu \mathrm{m}$ vs 47-52 $\mu \mathrm{m}$; B less than $76 \mu \mathrm{m}$ vs 72-92 $\mu \mathrm{m}$; C less than $68 \mu \mathrm{m} v s$ 70-86 $\mu \mathrm{m}$; D less than $112 \mu \mathrm{m} v s$ 111-134 $\mu \mathrm{m}$, respectively), less postovarian testes (4 vs 6-10, respectively), and longer testes (exceeding $52 \mu \mathrm{m} v s$ 17-45 $\mu \mathrm{m}$, respectively).

The new species also differs from $A$. popi in a shorter scolex (less than $416 \mu \mathrm{m} v s$ 426-580 $\mu \mathrm{m}$, respectively), a shorter muscular pad (less than $84 \mu \mathrm{m} v s$ 88-118 $\mu \mathrm{m}$, respectively), shorter lateral hooks (A less than $47 \mu \mathrm{m} v s$ 47-65 $\mu \mathrm{m}$; B less than $76 \mu \mathrm{m} v s$ 71-120 $\mu \mathrm{m}$; C less than $68 \mu \mathrm{m} v s$ 75-100 $\mu \mathrm{m}$; D less than $112 \mu \mathrm{m} v s$ 111-173 $\mu \mathrm{m}$, respectively), shorter medial hooks (A' less than $46 \mu \mathrm{m} v s$ 48-60 $\mu \mathrm{m}$; B' less than $74 \mu \mathrm{m} v s$ 75-119 $\mu \mathrm{m}$; C' less than $73 \mu \mathrm{m} v s$ 87-108 $\mu \mathrm{m}$; D' less than $116 \mu \mathrm{m}$ vs 120-175 $\mu \mathrm{m}$, respectively), less postovarian testes (4 vs 7-11, respectively), and larger testes (exceeding $52 \mu \mathrm{m}$ vs 28-50 $\mu \mathrm{m}$, respectively).

\section{DISCUSSION}

Sampling efforts focussed on parasitological observations of elasmobranchs off South Africa have been extremely sparse (Smit and Hadfield 2015, Schaeffner and Smit 2019). This particularly applies to the spotted skate, 
Raja straeleni, a relatively common species along the western and southern coastlines of southern Africa that has only once been examined for cestode infections (see Caira et al. 2014). Caira et al. (2014) discovered a new diphylidean cestode, a species that has not been encountered in the present study. On a global scale, a total of 18 species of Acanthobothrium have thus far been reported from 12 of the 23 valid species of Raja Linnaeus (Global Cestode Database 2020), clearly expressing the fact that host species are not limited to the infection of merely a single species of Acanthobothrium. Not only has this been previously reported in multiple studies (Fyler et al. 2009, Fyler and Caira 2010, Maleki et al. 2015), but this observation was also reflected in the present study, where four new species have been described from a single host species.

The present study marks the first to report species of Acanthobothrium from South Africa. With the addition of these four species, a total of 207 valid species of Acanthobothrium are currently recognised worldwide (Caira et al. 2017, Franzese and Ivanov 2018, 2020, Maleki et al. 2018, 2019, Rodríguez-Ibarra et al. 2018, Zaragoza-Tapia et al. 2019, 2020), making the taxonomic classification of new species, and intrageneric comparisons between congeners within this genus taxing (Ghoshroy and Caira 2001). Hence, in the interest of simplifying this matter, Ghoshroy and Caira (2001) have developed a category classification system on the basis of four morphological characteristics. The South African species all measure less than $15 \mathrm{~mm}$ in total length, with fewer than 50 proglottids, fewer than 80 testes, and an asymmetric ovary, designating all of them as category 2 species.

Comparisons between the four species presented in the current study suggest the possibility that these congeners could be each other's closest relatives. This assumption, however, is not only grounded upon the fact that these species resembled each other in numerous morphological characteristics, but also due to the presence of four synhospitalic congeners parasitising the same host species (Caira and Tracy 2003, Caira et al. 2004, Fyler and Caira 2006). To ensure that the South African species are in fact new to science, interspecific comparisons were made between all category 2 species recognised worldwide.

With the addition of the South African species, the total number of species of Acanthobothrium allocated to category 2 increased to 51 species. With this still being quite a substantial number of species, the South African congeners are very easily distinguished from all except two of these congeners by the presence of postovarian testes, undoubtably being a very interesting, yet highly unusual feature among species of Acanthobothrium (see Fyler et al. 2009, Fyler and Caira 2010, Maleki et al. 2015). In point of fact, this feature has been previously documented in merely $6 \%$ (12 out of 203) of all species of Acanthobothrium known to infect elasmobranchs (Subhapradha 1955, Robinson 1959, Campbell and Beveridge 2002, Fyler and Caira 2006, Reyda and Caira 2006, Twohig et al. 2008, Fyler et al. 2009, Fyler and Caira 2010, Maleki et al. 2015).

The descriptions of Acanthobothrium microhabentes, A. microtenuis, A crassus and $A$. dolichocollum increases the total number of species of Acanthobothrium known to possess postovarian testes to 16 species. Interestingly, with respect to the 12 previously reported species of Acanthobothrium known to bear this feature, all of these species were reported from hosts in waters of the Indo-Pacific Ocean (Fyler et al. 2009, Fyler and Caira 2010, Maleki et al. 2015), consequently suggesting that this feature might be restricted to this particular geographical region (Fyler and Caira 2006, Reyda and Caira 2006, Twohig et al. 2008, Fyler et al. 2009, Maleki et al. 2015). However, this could be argued, because species with this same feature off the south-western coast of South Africa clearly contradict the earlier conception.

To date, the majority of species reported to possess postovarian testes, however, seems to be identified as category 1 species, with seven species assigned to category 1 , six to category 2, one to category 3 , and two to category 4 (Twohig et al. 2008, Fyler et al. 2009, Fyler and Caira 2010, Maleki et al. 2015, present study). These congeners, including the South African species, all seem to parasitise host species from the families Dasyatidae and Rajidae. Seven species (Acanthobothrium cannoni Campbell et Beveridge, 2002, A. foulki Reyda et Caira, 2006, A. larsoni Reyda et Caira, 2006, A. marymichaelorum Twohig, Caira et Fyler, 2008, A. saliki Fyler et Caira, 2006, Acanthobothrium popi and A. zimmeri Fyler, Caira et Jensen, 2009) are reported from species of Himantura Müller et Henle (Campbell and Beveridge 2002, Fyler and Caira 2006, Reyda and Caira 2006, Twohig et al. 2008), six (A. blairi Campbell et Beveridge, 2002, A. microhabentes, A. microtenuis, A. crassus, A. dolichocollum and $A$. wedli Robinson, 1959) from species of Raja (Campbell and Beveridge 2002, Robinson 1959, present study), two (Acanthobothrium bobconniorum and A. jamesi Maleki, Malek et Palm, 2015) from species of Rhynchobatus Müller et Henle (Fyler and Caira 2010, Maleki et al. 2015), and one (A. southwelii Subhapradha, 1955) from Rhinobatos schlegelii Müller et Henle (Subhapradha 1955).

The South African congeners not only parasitise the same host species, but also share the rare feature of postovarian testes with 12 other species of Acanthobothrium. This makes the possibility of their relatedness even more evident. Given the fact that two other species with postovarian testes have also been documented in two other species of Raja (i.e. Zearaja nasuta [Müller et Henle], and Spiniraja whitleyi [Iredale]), the four new congeners might not only be grouped together as each other's closest relatives, but also with the 12 species of Acanthobothrium exhibiting the same unique feature, indorsing the notion that these species might comprise their own monophyletic clade (Fyler and Caira 2010). Moreover, as this is the first time that species of Acanthobothrium have been reported in R. straeleni, we can assume that this is the result of a single host invasion. Conversely, molecular analyses conducted by Fyler et al. (2009), including numerous synhospitalic congeners, concluded that these species do not represent closely related lineages. Fyler and Caira (2010) conducted a similar study, subsequently reaching the same conclusion. 
Phylogenetic trees do not only serve insights on host associations but also on the geographical distribution of species. According to earlier studies (Goldstein 1967, Williams 1969, Ghoshroy and Caira 2001, Fyler 2009), congeners displaying the same geographical affinities are more likely to group together. Surprisingly, species of Acanthobothrium parasitising the same host species of different geographical localities do not group in the same clade (Fyler 2009).

If a phylogenetic tree would display the four new species as distinct or independent lineages it would indicate that the infection of $R$. straeleni does not resemble a single host invasion as previously suggested, but rather be the result of multiple disparate host invasions (Fyler 2009). Regardless of the host's specific nature, extensive host substitutions may have occurred throughout a much longer evolutionary time, accordingly proceeding unnoticed during shortlived investigations (Fyler 2009). The combined effect of different geographical affinities as well as host substitution possibly resulted in an extraordinary host specificity, as they have been documented from eight of 11 elasmobranch orders (Caira et al. 2017).

This is truly intriguing, considering the fact that the South African species are the first species to possess postovarian testes outside of the Indo-Pacific realm. Furthermore, the host from which the species were obtained, $R$. straeleni, has only been documented to populate the Eastern Atlantic Ocean from the coastline of the western Sahara to southern Africa. Nevertheless, regardless of geographical affinities, the possibility of potential relatedness between species of Acanthobothrium possessing this rare feature still persists, supported by the fact that two of these species (i.e. A. popi and A. zimmeri) have already grouped together, during a molecular study performed by Fyler et al. (2009). Unfortunately, as of yet, the degree of relatedness among these unique species is still unknown, recognising the need for further investigation and a collection of additional specimens of $R$. straeleni from the same localities. A more conclusive molecular analysis including both the South African and Indo-Pacific species is furthermore fundamental in defining their phylogenetic relationships, informing us on whether these species do, in fact, form a monophyletic clade.

In addition, a molecular phylogenetic analysis on newly collected specimens will reveal their phylogenetic position and will highlight new perspectives on the evolutionary relationships between these cestodes and their elasmobranch hosts. With merely $9 \%$ (18 of 204) of elasmobranchs (Ebert and van Hees 2015, Schaeffner and Smit 2019) off southern Africa examined for cestode infections, it is also expected that the species diversity of cestodes infecting elasmobranchs in South African waters is much higher than currently reported (Schaeffner and Smit 2019) and future large-scale surveys on elasmobranch parasites will, without any doubt, lead to numerous new species discoveries.
Caira and Jensen (2017) estimated that 5,126 species of cestodes infect approximately 1,269 elasmobranch species worldwide, representing an average of four cestode species per elasmobranch host. As a consequence, the diversity of cestodes in the waters of South Africa is predicted to be either equal to, or, more likely, greater than the diversity of the chondrichthyan hosts present in these waters (Schaeffner and Smit 2019). Nevertheless, the current extensive and rapid rate of loss in biodiversity, not just in this region, but globally, limits the time remaining for the discovery and description of the cestode diversity. However, since species of Acanthobothrium are known to parasitise multiple elasmobranch orders, along with the ability to switch hosts, parasites of this genus could possibly be able to avoid extinction. Nonetheless, when accounting other cestode orders and genera parasitising elasmobranchs (i.e. cestodes without the ability to switch hosts), the loss of parasite diversity would then likely be higher than that of their hosts (Dobson et al. 2008). This is alarming given this will likely result in the extinction of numerous cestode species before they have even been discovered.

New, sustainable conservation schemes should be enforced, including a combination of multidisciplinary approaches. Hereby, information can be gained from parasites, providing us with a better understanding of the host, such as its evolutionary and demographic history and migratory patterns (Gomez and Nichols 2013). Collections of additional hosts and localities, such as the ocean basins surrounding southern Africa, which have previously not been properly explored, are required in this regard. New studies should also be concurrent with previously applied methods (i.e. taxonomy, molecular systematics) and the incorporation and implementation of novel, multisource approaches (i.e. biogeography, ecology, conservation science, ecotoxicology). When we consider to use these parasites as indicator organisms for pollution and global change, we may yield a much better understanding on the evolutionary interrelationships of host-parasite systems present within our world's remarkable ecosystems, contributing to various scientific fields, and ultimately contributing to the conservation of declining populations of endangered species and positive environmental change.

Acknowledgements. We are very grateful to the members of the South African Shark Conservancy for their collaboration and assistance in the field, especially Megan McCord, Björn von Düring, Natalia Drobniewska and Guy Paulet. We would also like to thank the Unit for Environmental Sciences and Management, North-West University (NWU) for the use of field equipment and laboratory facilities. Additional thanks go to our colleagues Ruan Gerber, Chantelle Pretorius, and Rian Pienaar from the NWU-Water Research Group who assisted with collection of samples. Furthermore, we would like to thank Anine Jordaan for taking SEM micrographs of specimens as well as Willie Landman for desktop SEM micrographs. This work was supported by a NWU postdoctoral fellowship to BCS. This is contribution No. 477 from the NWU-Water Research Group. 


\section{REFERENCES}

Caira J.N., Jensen K. 2014: A digest of elasmobranch tapeworms. J. Parasitol. 100: 373-391.

Caira J.N., Jensen K. (EDs.) 2017: Planetary Biodiversity Inventory (2008-2017): Tapeworms from Vertebrate Bowels of the Earth. The University of Kansas Natural History Museum, Special Publication no. 25, Lawrence, 463 pp.

Caira J.N., Jensen K., Fyler C.A. 2018: A new genus of tapeworm (Cestoda: Onchoproteocephalidea) from sawfish (Elasmobranchii: Pristidae). J. Parasitol. 104: 133-144.

Caira J.N., Jensen K., Ivanov V.A. 2017. Onchoproteocephalidea II. In: J.N. Caira and K. Jensen (Eds.), Planetary Biodiversity Inventory (2008-2017): Tapeworms from Vertebrate Bowels of the Earth. The University of Kansas Natural History Museum. Special Publication no. 25, pp. 279-304.

Caira J.N., Jensen K., Waeschenbach A., Olson P.D., LitTLEWOOD D.T.J. 2014: Orders out of chaos - molecular phylogenetics reveals the complexity of shark and stingray tapeworm relationships. Int. J. Parasitol. 44: 55-73.

Caira J.N., Tracy R. 2003: Two new species of Yorkeria (Tetraphyllidea: Onchobothriidae) from Chiloscyllium punctatum (Elasmobanchii: Hemiscyullidae). J. Parasitol. 88: 1172-1180.

Caira J.N., Tracy R., Euzet L. 2004: Five new species of Pedibothrium (Tetraphyllidea: Onchobothriidae) from the tawny nurse shark, Nebrius ferrugineus, in the Pacific Ocean. J. Parasitol. 90: 286-300.

Campbell R.A., Beveridge I. 2002: The genus Acanthobothrium (Cestoda: Tetraphyllidea: Onchobothriidae) parasitic in Australian elasmobranch fishes. Invertebr. Syst. 16: 237-344.

de Chambrier A., Scholz T., Mariaux J., Kuchta R. 2017: Onchoproteocephalidea I Caira, Jensen, Waeschenbach, Olson \& Littlewood, 2014. In: J.N. Caira and K. Jensen (Eds.), Planetary Biodiversity Inventory (2008-2017): Tapeworms from Vertebrate Bowels of the Earth. University of Kansas, Natural History Museum, Special Publication No. 25, Lawrence, KS, USA, pp. 251-277.

Dobson A., Lafferty K.D., Kuris A.M., Hechinger R.F., Jet W. 2008: Homage to Linnaeus: How many parasites? How many hosts? Proc. Natl. Acad. Sci. 105: 11482-11489.

Ebert D., van Hees K.E. 2015: Beyond jaws: rediscovering the 'lost sharks' of southern Africa. Afr. J. Mar. Sci. 37: 141-156.

FranZeSE S., Ivanov V.A. 2018: Hyperapolytic species of Acanthobothrium (Cestoda: Onchoproteocephalidea) from batoids off Argentina. Parasitol. Int. 67: 431-443.

Franzese S., Ivanov V.A. 2020: Two new species of Acanthobothrium Blanchard, 1848 (Cestoda: Onchoproteocephalidea) from rajiform batoids off Argentina. Folia Parasitol. 67: 016.

FyleR C.A. 2009: Systematics, Biogeography and Character Evolution in the Tapeworm Genus Acanthobothrium van Beneden, 1850. ProQuest Dissertations Publishing, University of Conneticut, $200 \mathrm{pp}$.

Fyler C.A. 2011: An extremely hyperapolytic Acanthobothrium species (Cestoda: Tetraphyllidea) from the Japanese wobbegong, Orectolobus japonicus (Elasmobranchii: Orectolobiformes) in Taiwan. Comp. Parasitol. 78: 4-14.

Fyler C.A., CAIRA J.N. 2006: Five new species of Acanthobothrium (Tetraphyllidea: Onchobothriidae) from the freshwater stingray Himantura chaophraya (Batoidea: Dasyatidae) in Malaysian Borneo. J. Parasitol. 92: 105-125.

Fyler C.A., CAIRA J.N. 2010: Phylogenetic status of four new species of Acanthobothrium (Cestoda: Tetraphyllidea) parasitic on the wedgefish Rhynchobatus laevis (Elasmobranchii: Rhynchobatidae): implications for interpreting host associations. Invertebr. Syst. 24: 419-433.

Fyler C.A., CAIra J.N., Jensen K. 2009: Five new species of Acanthobothrium (Cestoda: Tetraphyllidea) from an unusual species of Himantura (Rajiformes: Dasyatidae) from northern Australia. Folia Parasitol. 56: 107-128.

Ghoshroy S., Caira J.N. 2001: Four new species of Acanthobothrium (Cestoda: Tetraphyllidea) from the whiptail stingray Dasyatis brevis in the Gulf of California. J. Parasitol. 87: 354372 .

Global Cestode Database 2020: World Wide Web electronic publication. http://tapewormdb.uconn.edu. Accessed: 22 February 2020.

Goldstein R.J. 1967: The genus Acanthobothrium van Beneden, 1849 (Cestoda: Tetraphyllidea). J. Parasitol. 53: 455-483.

Gomez A., Nichols E. 2013: Neglected wild life: parasitic biodiversity as a conservation target. Int. J. Parasitol. 2: 222-227.

IvANOV V.A. 2005: A new species of Acanthobothrium (Cestoda: Tetraphyllidea: Onchobothriidae) from the ocellate river stingray, Potamotrygon motoro (Chondrichthyes: Potamotrygonidae), in Argentina. J. Parasitol. 91: 390-396.

Maleki L., Malek M., Palm H.W. 2013: Two new species of Acanthobothrium (Tetraphyllidea: Onchobothriidae) from Pastinachus cf. sephen (Myliobatiformes: Dasyatidae) from the Persian Gulf and Gulf of Oman. Folia Parasitol. 60: 448-456.

MaleKi L., MaleK M., PALM H.W. 2015: Four new species of Acanthobothrium van Beneden, 1850 (Cestoda: Onchoproteocephalidea) from the guitarfish, Rhynchobatus cf. djiddensis (Elasmobranchii: Rhynchobatidae), from the Persian Gulf and Gulf of Oman. Folia Parasitol. 62: 012.

Maleki L., Malek M., Palm H.W. 2019: Five new species of Acanthobothrium (Cestoda: Onchoproteocephalidea) from the longtailed butterfly ray, Gymnura cf. poecilura (Elasmobranchii: Gymnuridae), from the Persian Gulf and Gulf of Oman. Zootaxa 4609: 289-307.

Maleki L., Malek M., Rastgoo A. 2018: Acanthobothrium chabahariense n. sp. (Cestoda: Onchoproteocephalidea) in the cowtail stingray Pastinachus cf. sephen (Myliobatiformes: Dasyatidae) from the Gulf of Oman, Iran. J. Genet. Resour. 4: 114-121.

Reyda F.B., CAIRA J.N. 2006: Five new species of Acanthobothrium (Cestoda: Tetraphyllidea) from Himantura uarnacoides (Myliobatiformes: Dasyatidae) in Malaysian Borneo. Comp. Parasitol. 73: 49-71.

Robinson E.S. 1959: Some new cestodes from New Zealand marine fishes. Trans. R. Soc. N. Z. 86: 381-392.

Rodríguez-Ibarra E., Pulido-Flores G., Violante -González J., Monks S. 2018: A new species of Acanthobothrium (Eucestoda: Onchobothriidae) in Aetobatus cf. narinari (Myliobatidae) from Campeche, México. Braz. J. Vet. Parasitol. 27: $67-74$

Schaeffner B.C., Smit N.J. 2019: Parasites of cartilaginous fishes (Chondrichthyes) in South Africa - a neglected field of marine science. Folia Parasitol. 66: 002.

Smit N.J., Hadfield K.A. 2015: Marine fish parasitology in South Africa: history of discovery and future direction. Afr. Zool. 50: 79-92.

Spalding M.D., Fox H.E., Allen G.R., Davidson N., Ferdaña Z.A., Finlayson M., Halpern B.S., Jorge M.A., Lombana A., Lourie S.A., Martin K.D., McManus E., Molnar J., RecChia C.A., Robertson J. 2007: Marine ecoregions of the world: a bioregionalization of coastal and shelf areas. Bioscience 57: 573-583.

SubHAPRADHA C.K. 1955: Cestode parasites of fishes of Madras. Ind. J. Helminthol. 7: 41-132.

Tazerouti F., Kechemir-Issad N., Euzet L. 2009: Acanthobothrium minus $\mathrm{n}$. sp. (Tetraphyllidea: Onchobotriidae) parasite de Raja asterias (Elasmobranchii: Rajidae) en Méditerranée. Parasite 16: 203-207. 
Twohig M.E., Caira J.N., Fyler C.A. 2008: Two new cestode species from the dwarf whipray, Himantura walga (Batoidea: Dasyatidae), from Borneo with comments on site and mode of attachment. J. Parasitol. 94: 1118-1127.

Williams H.H. 1969: The genus Acanthobothrium Beneden, 1849 (Cestoda: Tetraphyllidea). Nytt Mag. Zool. 17: 1-56.

Yang C., Sun Y., Zhi T., Iwaki T., Reyda F.B., Yang T. 2016 Two new and one redescribed species of Acanthobothrium (Cestoda: Onchoproteocephalidea: Onchobothriidae) from Dasyatis akajei (Myliobatiformes: Dasyatidae) in the China Sea. Zootaxa 4169: 286-300.
Zaragoza-Tapia F., Pulido-Flores G., Monks S. 2020: Three new species of Acanthobothrium Blanchard, 1848 (Cestoda: Onchoproteocephalidea) in stingrays (Dasyatidae) from the Pacific coast in Mexico. Zootaxa 4766: 139-172.

Zaragoza-Tapia F., Pulido-Flores G., Violante-González J., Monks S. 2019: Two new species of Acanthobothrium Blanchard, 1848 (Onchobothriidae) in Narcine entemedor Jordan \& Starks, 1895 (Narcinidae) from Acapulco, Guerrero, Mexico. ZooKeys 852: 1-21.

Cite this article as: Van Der Spuy L., Smit N.J., Schaeffner B.C. 2020: Four new species of Acanthobothrium van Beneden, 1849 (Cestoda: Onchoproteocephalidea) from the spotted skate, Raja straeleni Poll, off the Western Cape, South Africa. Folia Parasitol. 67: 036. 